\title{
Non-Thermal Plasma, as a New Physicochemical Source, to Induce Redox Imbalance and Subsequent Cell Death in Liver Cancer Cell Lines
}

\author{
Barbora Smolkováa Mariia Lunova ${ }^{\mathrm{a}, \mathrm{b}}$ Anna Lynnyk ${ }^{\mathrm{a}} \quad$ Mariia Uzhytchak $^{\mathrm{a}}$ \\ Olexander Churpita ${ }^{a}$ Milan Jirsa ${ }^{b}$ Šárka Kubinováa,c Oleg Lunova \\ Alexandr Dejneka ${ }^{a}$
}

anstitute of Physics of the Czech Academy of Sciences, Prague, Czech Republic, ' Institute for Clinical \& Experimental Medicine (IKEM), Prague, Czech Republic, Institute of Experimental Medicine of the Czech Academy of Sciences, Prague, Czech Republic

\section{Key Words}

Oxidative stress • Reactive oxygen species • Apoptosis • Non-thermal plasma • Stress resistance - p53

\begin{abstract}
Background/Aims: Alteration of cancer cell redox status has been recognized as a promising therapeutic implication. In recent years, the emerged field of non-thermal plasma (NTP) has shown considerable promise in various biomedical applications, including cancer therapy. However, understanding the molecular mechanisms procuring cellular responses remains incomplete. Thus, the aim of this study was a rigorous biochemical analysis of interactions between NTP and liver cancer cells. Methods: The concept was validated using three different cell lines. We provide several distinct lines of evidence to support our findings; we use various methods (epifluorescent and confocal microscopy, clonogenic and cytotoxicity assays, Western blotting, pharmacological inhibition studies, etc.). Results: We assessed the influence of NTP on three human liver cancer cell lines (Huh7, Alexander and HepG2). NTP treatment resulted in higher anti-proliferative effect against Alexander and Huh7 relative to HepG2. Our data clearly showed that the NTP-mediated alternation of mitochondrial membrane potential and dynamics led to ROS-mediated apoptosis in Huh7 and Alexander cells. Interestingly, plasma treatment resulted in p53 down-regulation in Huh7 cells. High levels of Bcl-2 protein expression in HepG2 resulted in their resistance in response to oxidative stress- mediated by plasma. Conclusion: We show thoroughly time- and dose-dependent kinetics of ROS accumulation in HCC cells. Furthermore, we show nuclear compartmentalization of the superoxide anion triggered by NTP. NTP induced apoptotic death in Huh7 liver cancer cells
\end{abstract}




\section{Cellular Physiology \\ \begin{tabular}{ll|l} 
and Biochemistry & $\begin{array}{l}\text { DOl: } 10.33594 / 000000009 \\
\text { Published online: } 18 \text { February } 2019\end{array}$ & $\begin{array}{l}\text { C } 2019 \text { The Author(s). Published by } \\
\text { Cell Physiol Biochem Press GmbH\&Co. KG }\end{array}$
\end{tabular} \\ Smolková et al.: Molecular Mechanisms of Non-Thermal Plasma Action on Cancer Cells}

via simultaneous downregulation of mutated p53, pSTAT1 and STAT1. Contrary, hydrogen peroxide treatment results in autophagic cell death. We disclosed detailed mechanisms of NTP-mediated alteration of redox signalling in liver cancer cells.

(C) 2019 The Author(s). Published by Cell Physiol Biochem Press GmbH\&Co. KG

\section{Introduction}

Despite recent progress in cancer therapies [1-3], hepatocellular carcinoma (HCC) represents the second biggest cause of mortality [2,3] with steadily rising incidence [4]. HCC becomes a major health problem due to lack of novel effective therapeutics [2,5]. Thus, development of other effective HCC treatment modalities is of a great importance.

Mounting evidences suggest that tumours possess altered redox balance and deregulated redox signalling that is strongly associated with malignant transformation and resistance to conventional treatments [6, 7]. Specifically in HCC, oxidative stress pathway is constitutively activated $[8,9]$. Sustained reactive oxygen species (ROS) production results in developing an efficient mechanism of ROS detoxification and cancer survival under prooxidizing conditions $[6,7]$. Thus, dependency of cancer cells from their antioxidant systems was recognized as a promising target to induce cell death [6, 7]. However, clinical trials with several antioxidants as potential HCC treatment revealed serious adverse effects including increased cancer incidence [10]. To circumvent them, complex treatment modalities that combine alteration of redox signalling with blockade of the key antioxidant systems were developed $[6,7,11]$. Disturbance of redox status showed promising results in HCC [12-15]; however, such treatments were not completely satisfactory in HCC patients diagnosed at advanced stages and those with complications $[16,17]$.

Non-thermal plasma (NTP) that alters redox signalling in cells has emerged recently $[18,19]$. NTP is a partially ionized gas that contains a chemically complex and reactive environment that includes ions, electrons, free radicals, UV radiation, and neutral molecules [20]. A bust of studies has shown numerous biological and medical applications of NTP ranging from microorganism deactivation [21, 22], neural differentiation [23] and wound healing [24, 25], to cancer treatment [19, 26-29]. Notwithstanding such extensive research the exact action mechanisms of plasma on cells and humans are not well understood. Growing number of studies suggests that major factors underlying the effect of plasmacell interaction are reactive oxygen (ROS) and reactive nitrogen species (RNS) whereas the influence of others is negligible [22, 23, 30,31].

The aim of this study was to investigate cellular and molecular effects of air NTP exerted on distinct HCC cell lines. Our study demonstrates that NTP treatment resulted in higher anti-proliferative activity against Huh7 and Alexander cells relative to HepG2. The cellular response involves increased intracellular accumulation and production of chemically active ROS and RNS. Moreover, our study identifies p53 tumour suppressor protein as cellular NTP-effector in HCC cell lines, which mediates ROS-induced cell death in response to acute NTP treatment. HepG2 cell line showed greater degree of resistance in response to oxidative stress mediated by plasma due to the overexpression of Bcl-2 protein. Taking together, we elucidated detailed cell line-specific mechanisms altering redox signalling in the absence of other activators which may provide a basis for better controlled biomedical applications.

\section{Materials and Methods}

\section{Chemicals and antibodies}

The following fluorescent probes were used: Cellular ROS/Superoxide Detection Assay Kit (Abcam, Cambridge, United Kingdom) to detect the generation of ROS and superoxide; and acridine orange (5 $\mu \mathrm{g} / \mathrm{ml}$ ) to monitor lysosomal integrity (Thermo Fisher Scientific, Waltham, MA); JC-1 (1 $\mu \mathrm{M}$ ) to monitor mitochondrial membrane potential (Thermo Fisher Scientific) and CellEvent ${ }^{\mathrm{TM}}$ Caspase-3/7 Green Assay Kit to detect caspase-3 activation (Thermo Fisher Scientific). To investigate mitochondrial ROS, cells were 


\section{Cellular Physiology Cell Physiol Biochem 2019:52:119-140

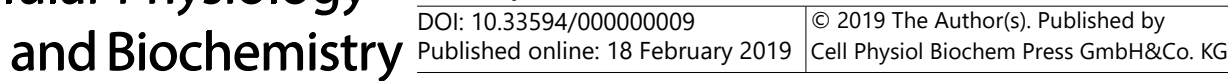 \\ Smolková et al.: Molecular Mechanisms of Non-Thermal Plasma Action on Cancer Cells}

loaded with MitoTracker ${ }^{\circledR}$ red CM- $\mathrm{H}_{2}$ XRos (reduced form of MitoTracker ${ }^{\circledR}$ red; $0.5 \mu$ M; Thermo Fisher Scientific) by incubating them for $15 \mathrm{~min}$. The cell-permeant SYTO 13 green fluorescent nucleic acid stain (5 $\mu \mathrm{M}$; Thermo Fisher Scientific) was used to label nucleus. Apoptosis was assessed using Apoptosis Detection Kit (Thermo Fisher Scientific). Nuclei were counterstained with either Hoechst 33342 or NucRed ${ }^{\text {TM }}$ Live 647 ReadyProbes $^{\mathrm{TM}}$ Reagent (both from Thermo Fisher Scientific). The optimal incubation time for each probe was determined experimentally.

The following reagents were used: $N$-acetyl-L-cysteine (NAC, $5 \mathrm{mM}$ ) to scavenge ROS (Sigma-Aldrich, St. Louis, MO); staurosporine (STS, $2 \mu \mathrm{M}$ ) as a known inducer of apoptosis (Abcam, Cambridge, United Kingdom); pyocyanin (200 $\mu \mathrm{M}$; Abcam) and $\mathrm{H}_{2} \mathrm{O}_{2}$ (0.1-10 mM; Sigma-Aldrich) as a known ROS inducers; ABT-737 $(1-10 \mu \mathrm{M})$ as a potent and selective inhibitor of Bcl-2, EC50 $=30.3 \mathrm{nM}$ (Selleckchem, Munich, Germany). All chemicals used in the study are summarized in Table 1.

\section{Cell culture and liver sample}

Human hepatocellular carcinoma cell lines Huh7 obtained from the Japanese Collection of Research Bioresources (JCRB), HepG2 (American Type Culture Collection, ATCC) and Alexander (PLC/PRF/5, ATCC) were cultured in EMEM medium (ATCC) supplemented with $10 \%$ fetal bovine serum (FBS, Thermo Fisher Scientific) as recommended by the supplier. Cultures were kept in a humidified $5 \% \mathrm{CO}_{2}$ atmosphere at $37^{\circ} \mathrm{C}$ and the medium was changed once a week. Liver tissue sampling was approved by the Clinical and Experimental Medicine and the Thomayer University Hospital Research Ethics Committee and the Ethics Committee of the Third Faculty of Medicine, Charles University in Prague.

\section{Plasma treatment}

To produce uniform non-thermal plasma for application in biomedicine, we utilized specific plasma system published previously [21, 30, 32]. For plasma generation air was used as working gas. The plasma treatment procedure we described in details in [21, 30,32]. Briefly, air was supplied through a gas inlet and then was ionized in the pores of the ceramic membrane. The input voltage was about $600 \mathrm{~V}$, electric current $167 \mathrm{~mA}$, and the power was $100 \mathrm{~W}$; such a high voltage supply resulted in electron energy of about $0.5 \mathrm{keV}$. Cells grown to $70 \%$ confluence were exposed to plasma from the device located $10 \mathrm{~mm}$ away, for $5,10,15,25,30,45$ and $60 \mathrm{~s}$. Before the treatment, the medium was removed from culture wells and then $50 \mu \mathrm{l}$ of medium was added to prevent the cells from drying up. After the plasma treatment, the remaining medium was replaced with a fresh one. The plasma density increased with an increase in applied voltage. The operation voltage was kept constant as $0.5 \mathrm{kV}$ for all experiments. The majority of experiments were done in 96-well plates in quadruplicates, with at least 3 or 4 independent experiments. Immunofluorescence and immunoblot assays were done on cells irradiated by plasma in 24-well plates. In order to avoid crossstimulation of neighbouring wells, we treated wells by plasma through a protective plastic sheet $(2 \mathrm{~mm}$ thickness) with a hole of the same size as the plasma nozzle [30]. Moreover, we seeded cells with one well gap filled with sterile water to be sure that different exposures were not cross-reacting [30].

Table 1. List of fluorescent reagents, inhibitors and other chemicals used in the study

\begin{tabular}{lcc}
\hline Reagent & Manufacturer & Catalogue \\
\hline WST-1 & Roche Diagnostics & 11644807001 \\
Cellular ROS/Superoxide Detection Assay Kit & Abcam & ab139476 \\
Acridine Orange & Thermo Fisher Scientific & A3568 \\
Apoptosis Detection Kit & Thermo Fisher Scientific & V13245 \\
JC-1 & Thermo Fisher Scientific & T3168 \\
MitoTracker@ red CM-H ${ }_{2}$ XRos & Thermo Fisher Scientific & M7513 \\
NucRed ${ }^{\text {TM }}$ Live 647 ReadyProbes ${ }^{\text {TM }}$ Reagent & Thermo Fisher Scientific & R37106 \\
SYTO 13 green & Thermo Fisher Scientific & S7575 \\
CellEvent@ Caspase-3/7 Green Assay Kit & Thermo Fisher Scientific & C10740 \\
Hoechst 33342 & Thermo Fisher Scientific & 62249 \\
N-acetyl-L-cysteine & Sigma-Aldrich & A7250 \\
staurosporine & Abcam & ab120056 \\
pyocyanin & Abcam & ab141099 \\
ABT-737 & Selleckchem & S1002 \\
\hline
\end{tabular}




\section{Cellular Physiology Cell Physiol Biochem 2019:52:119-140 \\ \begin{tabular}{l|l}
\hline DOI: 10.33594/000000009 & ( 2019 The Author(s). Published by
\end{tabular} \\ \begin{tabular}{l|l} 
Published online: 18 February 2019 Cell Physiol Biochem Press GmbH\&Co. KG \\
\hline
\end{tabular} \\ Smolková et al.: Molecular Mechanisms of Non-Thermal Plasma Action on Cancer Cells}

Further, to make plasmas spatially well localized, we developed a plastic concentrator for the nozzle [30]. Being aware that NTPs might change the $\mathrm{pH}$ of liquids, we monitored $\mathrm{pH}$ changes upon plasma treatment. The $\mathrm{pH}$ of the media solution was measured with a pH probe (Oakton pHTestr30) before and after the solution was treated with the plasma, for a given amount of time $(5,10,15,25,30,45$ and $60 \mathrm{~s})$. All irradiation times by both plasmas did not change the $\mathrm{pH}$ of the cell culture media; the $\mathrm{pH}$ was at the range of 7.4. This observation is not surprising, because it has been shown that short-term exposure for less than 4 min does not lead to $\mathrm{pH}$ changes in media [33].

Additionally, we performed power measurements of UV production by air NTP utilizing UV light meter (Lutron YK 35UV). Power measurements of UV production, where the power density for air was lower than $1 \mu \mathrm{W} / \mathrm{cm}^{2}$, which is at least one order of magnitude lower than the minimal power density needed to have any effect on living cells [34].

\section{Cell viability assay}

Cell viability was analyzed by WST-1 assay (Roche Diagnostics, Basel, Switzerland), that is based on the cleavage of tetrazolium salt WST-1 by cellular mitochondrial dehydrogenases, producing a soluble formazan salt. This conversion occurs only in viable cells, thus allowing accurate spectrophotometric quantification of the number of metabolically active cells in the culture. Cells were seeded onto 96-well plates at a density of 8000 cells per well and treated with plasma for 5, 10,15, 25, 30, 45 and $60 \mathrm{~s}$. 24 or $72 \mathrm{~h}$ after the treatment, WST-1 reagent was added to each dish and incubated for $2 \mathrm{~h}$ at $37^{\circ} \mathrm{C}$ to form formazan. The absorbance was measured using a TECAN microplate reader SpectraFluor Plus (TECAN, Mannedorf, Switzerland) at $450 \mathrm{~nm}$. Readings were done in quadruplicates; three independent experiments were performed for each

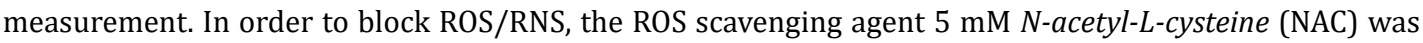
added to the complete culture medium. In experiments with pharmacological inhibitors, culture medium was supplemented with 1-10 $\mu \mathrm{M}$ ABT-737 (a potent and selective inhibitor of Bcl-2).

\section{Detection of intracellular ROS and RNS}

ROS and RNS levels were measured using Cellular ROS/Superoxide Detection Assay Kit (Abcam, Cambridge, United Kingdom). Briefly, cells were seeded onto 96-well black/clear bottom plates (BD Biosciences, Corning, CA) at a density of 8000 cells per well. Following this, plasma treatment cells were labeled with Oxidative Stress Detection Reagent (Green) for ROS detection and Superoxide Detection Reagent (Orange) according to the manufacturer's instructions (Abcam, Cambridge, United Kingdom). Fluorescence was then measured using a TECAN microplate reader SpectraFluor Plus. Readings were done in quadruplicates. As positive control treatment with either $500 \mu \mathrm{M} \mathrm{H}_{2} \mathrm{O}_{2}$ for $30 \mathrm{~min}$ or $200 \mu \mathrm{M}$ pyocyanin for $1 \mathrm{~h}$ were used. Quantification of ROS levels was done using the methods published earlier [35]. Briefly, we calculated fluorescence using the formula $\left[\left(\mathrm{F}_{\mathrm{t} 10}-\mathrm{F}_{\mathrm{t} 0}\right) / \mathrm{F}_{\mathrm{t} 0}\right]$, where $\mathrm{F}_{\mathrm{t} 10}$ is fluorescence at time 10 min (time needed for the dye to effectively label reactive oxygen species in cells) and $\mathrm{F}_{\mathrm{t} 0}$ - fluorescence at time $0 \mathrm{~min}$. The fluorescence, then, was normalized to the fluorescence of negative control giving a value of 'Relative ROS/Superoxide level'. We and others showed that this method is reliable and efficient for evaluating the potency of pro-oxidants and can be used to evaluate the efficacy of antioxidants against oxidative stress in cells $[21,30,35]$.

\section{Lysosomal stability assay utilizing Acridine Orange (AO)}

After plasma treatment cells were stained with $5 \mu \mathrm{g} / \mathrm{ml}$ acridine orange (AO, Thermo Fisher). Once inside the lysosomes, the metachromatic AO sensitizes the lysosomal membrane to photo-oxidation by blue light. Upon treatment-induced loss of the lysosomal $\mathrm{pH}$ gradient and subsequent leakage of AO into the cytosol, the emission spectrum of AO shifts from red to green. Hence, loss of lysosomal integrity can be measured as a 'loss of red fluorescence'. The accompanying decrease in fluorescence intensity was analysed by measuring intensity of red fluorescence utilizing TECAN microplate reader SpectraFluor Plus. The fluorescence, then, was normalized to the fluorescence of negative control giving a value of 'Fluorescence (AO) normalized'. Readings were done in quadruplicates; three independent experiments were performed for each measurement. 


\section{Cellular Physiology Cell Physiol Biochem 2019:52:119-140 \\ \begin{tabular}{l|l|l}
\hline DOI: 10.33594/000000009 2019 The Author(s). Published by \\
\hline
\end{tabular} \\ Published online: 18 February 2019 Cell Physiol Biochem Press GmbH\&Co. KG \\ Smolková et al.: Molecular Mechanisms of Non-Thermal Plasma Action on Cancer Cells}

\section{Quantification of mitochondrial membrane potential}

Cells were stained with $1 \mu \mathrm{M} \mathrm{JC}-1$ probe $5 \mathrm{~h}$ post plasma treatment for analysis of mitochondrial membrane potential $(\Delta \mathrm{m} \Phi)[36,37]$. JC-1 is a lipophilic cationic fluorescence dye with a dual emission wavelength. It accumulates in mitochondria depending on $\Delta \mathrm{m} \Phi$ and is present either as monomer or oligomer (J-aggregate). The JC-1 monomer predominating in depolarized mitochondria emits green fluorescence $(\sim 530 \mathrm{~nm})$, whereas the oligomer forming in mitochondria with potentials more negative than $-140 \mathrm{mV}$ emits red fluorescence $(\sim 590 \mathrm{~nm})$. JC-1 has advantages over other cationic dyes in that it can selectively enter into mitochondria and reversibly change colour from red to green as the membrane potential decreases. In healthy cells with high mitochondrial $\Delta \mathrm{m} \Phi$, JC-1 spontaneously forms complexes known as J-aggregates with intense red fluorescence. On the other hand, in apoptotic or unhealthy cells with low $\Delta \mathrm{m} \Phi$, JC-1 remains in the monomeric form, which shows only green fluorescence. Hence, loss of mitochondrial membrane potential can be measured as a 'loss of red fluorescence'. Following staining, cells were imaged using Bio-Rad MRC-1024 laser scanning confocal microscope (BioRad, Hercules, CA). ImageJ software (NIH, Bethesda, MD) was used for image processing and fluorescence quantification.

\section{Detection of mitochondrial reactive oxygen species}

Mitochondria specific ROS were assessed as described previously [37]. Briefly, after NTP treatment cells were loaded with $5 \mu$ M SYTO 13 green and $0.5 \mu \mathrm{M}$ MitoTracker ${ }^{\circledR}$ red $\mathrm{CM}-\mathrm{H}_{2} \mathrm{XRos}$ for 15 min at $37^{\circ} \mathrm{C}$ in the dark and then imaged using Bio-Rad MRC-1024 laser scanning confocal microscope. ImageJ software was used for image processing and fluorescent micrograph quantification. Cellular fluorescence intensity was calculated by normalizing corrected total cell fluorescence (CTCF) of the full area of interest to average a single cell fluorescence. The net average CTCF intensity of a pixel in the region of interest was calculated for each image utilizing a previously described method [37].

\section{Caspase-3/7 activity assay}

Caspase-3/7 activation was detected utilizing the CellEvent ${ }^{\mathrm{TM}}$ Caspase-3/7 Green Assay Kit (Thermo Fisher Scientific). Cells were seeded onto 96-well black/clear bottom plates (BD Biosciences) at a density of 8000 cells per well. $6 \mathrm{~h}$ post plasma treatment, cells were stained with CellEvent ${ }^{\mathrm{TM}}$ Caspase-3/7 Green Assay Kit according to the manufacturer's instructions. The fluorescence was then measured using a TECAN microplate reader SpectraFluor Plus. Alternatively, cells were seeded in 35mm ibidi $\mu$ - dishes (Ibidi, Munich, Germany) and then imaged using Bio-Rad MRC-1024 laser scanning confocal microscope. As positive control $2 \mu \mathrm{M}$ staurosporine for $4 \mathrm{~h}$ was used.

\section{Detection of apoptosis}

The Dead Cell Apoptosis Kit (Thermo Fisher Scientific) was used to measure early apoptosis by detecting phosphatidylserine expression and membrane permeability. Cells were cultured in 24-well plate on glass cover slips coated with FBS and treated with plasma for 60s and incubated for $6 \mathrm{~h}$. $6 \mathrm{~h}$ post plasma treatment, cells were stained with Dead Cell Apoptosis Kit according to the manufacturer's instructions. Phosphatidylserine expression as an early sign of apoptosis was determined by the binding of Alexa Fluor 488 Annexin V, propidium iodide was used to differentiate necrotic cells. Hoechst 33342 was used as nucleus staining. After staining, cells were fixed by 4\% paraformaldehyde for $10 \mathrm{~min}$ at room temperature. As positive control $2 \mu \mathrm{M}$ staurosporine for $4 \mathrm{~h}$ was used. Fluorescence images were recorded with epifluorescent microscope IM-2FL (Optika Microscopes, Ponteranica, Italy). ImageJ software was used for image processing and fluorescent micrograph quantification.

\section{Cell extracts and western immunoblot analysis}

Aliquots of whole cell lysates [38, 39] containing equal amounts of protein were obtained using lysis buffer RIPA. Protein samples were subjected to SDS-PAGE electrophoresis, transferred to PVDF membranes. The membranes were blocked with $5 \%(\mathrm{w} / \mathrm{v})$ nonfat dried milk for $1 \mathrm{~h}$, then incubated with various specific primary antibodies listed in Table 2 at $4{ }^{\circ} \mathrm{C}$ overnight and detected as described [38, 39]. All antibodies used in the study are summarized in Table 2 . Supplements include non-cropped immunoblots (all supplementary material available online at www.cellphysiolbiochem.com). 


\section{Cellular Physiology Cell Physiol Biochem 2019:52:119-140 \\ \begin{tabular}{ll|l} 
and Biochemistry & $\begin{array}{l}\text { DOI: 10.33594/000000009 } \\
\text { Published online: 18 February } 2019\end{array}$ & $\begin{array}{l}\text { C } 2019 \text { The Author(s). Published by } \\
\text { Cell Physiol Biochem Press GmbH\&Co. KG }\end{array}$
\end{tabular}

\section{Confocal microscopy}

Nikon Diaphot 200 microscope

(Nikon, Tokyo, Japan) in combination with Bio Rad MRC-1024 confocal laser scanning imaging system have been used in this work for the visualization of cells. Fluorescence images were taken with the acquisition software Lasersharp 2000 v5.2 (BioRad). ImageJ software was used for image processing and quantification.
Table 2. List of antibodies used in western blotting and immunofluorescence analysis

\begin{tabular}{lcc}
\hline Primary antibody (dilution) & Clone/catalogue & Manufacturer \\
\hline Anti-Bcl-2 $(1: 1000)$ & 15071 & Cell Signaling Technology \\
Anti-p53 $(1: 1000)$ & 2527 & Cell Signaling Technology \\
Anti-LC3A/B $(1: 1000)$ & 12741 & Cell Signaling Technology \\
Anti-mTOR $(1: 1000)$ & L27D4 & Cell Signaling Technology \\
Anti-pmTOR $(1: 1000)$ & S2448 & Cell Signaling Technology \\
Anti-pSTAT1 $(1: 1000)$ & D3B7 & Cell Signaling Technology \\
Anti-STAT1 $(1: 1000)$ & E1710 & Santa Cruz Biotechnology \\
Anti- $\beta$-actin $(1: 2000)$ & $10 D 10$ & Thermo Fisher Scientific \\
Annexin V Alexa Fluor ${ }^{\mathrm{TM}} 488(1: 100)$ & V13245 & Thermo Fisher Scientific \\
Secondary antibody (dilution) & Clone/catalogue & Manufacturer \\
Anti-Mouse-HRP $(1: 10000)$ & G21040 & Thermo Fisher Scientific \\
Anti-Rabbit-HRP $(1: 10000)$ & G21234 & Thermo Fisher Scientific \\
\hline
\end{tabular}

\section{Clonogenic survival assay}

For clonogenic assays, single-cell suspensions were generated for each cell line and specified numbers of cells were seeded into 24-well tissue culture plates. Cells were allowed to adhere for $6 \mathrm{~h}$, and then irradiated with plasma. Five days after the treatment colonies were stained with crystal violet method described in [40].

\section{Statistical analysis}

Quantitative results are present as mean \pm SEM. The statistical significance of differences between the groups was determined using ANOVA Fisher's LSD and Newman-Keuls tests. Differences were considered statistically significant at ${ }^{*} P<0.05$.

Experiments utilizing multi-well microtitre plates (e.g. cell viability, caspase 3/7 activity, ROS and RNS detection, lysosomal integrity, mitochondrial membrane potential) were conducted in accordance with guideline on randomization, spatial arrangement of samples and sampling number [41]. Readings were done in quadruplicates. Data were plotted for 3 independent experiments for each treatment.

For quantitative fluorescence microscopy analysis (analysis of mitochondria dynamics, mitochondrial ROS detection) we used rigorously defined guidelines for accuracy and precision quantification [42]. The sample size determination was based on a statistical method described in [43], which determines sample size for $95 \%$ confidence interval and 0.9 statistical power equal to 30 . Therefore, $n=30$ cells were used in quantification. Furthermore, to meet acceptable standards of data presentation [44], quantitative fluorescence microscopy data were shown by displaying the full dataset as scatter plots.

\section{Results}

NTP is more cytotoxic in Huh7 vs HepG2 cells due to distinct ROS accumulation

A number of studies have shown the anti-proliferative activity of NTP against different cancer cell lineages $[19,26,28,45,46]$. However, only limited number of reports compared NTP-induced effects on the same cancer model using different cell lines. It is worth noting here that glioblastoma cell lines displayed different sensitivities to plasma treatment [47]. Furthermore, only few studies showed potential anticancer effects on HCC cell lines [46, 48-50]. Indeed, ROS and lipid peroxide species generated by plasma eventually resulted in the HepG2 cell death [49]. Here, we analysed the physiochemical and biochemical processes that occur during NTP treatment of different HCC cell lines. Cytotoxic effects induced by NTP exerted on HepG2 and Huh7 cells were dose- and time-dependent (Fig. 1A; and 2A). Interestingly, NTP showed significantly higher cytotoxic activity against Huh7 cells compared to HepG2 (Fig. 1B; and 2A). The cytotoxic effect of NTP exerted on Huh7 and HepG2 was chased by colony formation (Fig. 1C). NTP treatment reduced tumorigenicity of Huh7; on the other hand, NTP had negligible effect on HepG2 colony formation (Fig. 1C).

It becomes more evident that ROS and RNS are major factors mediating the effect of plasma-cell interaction $[22,23,30,31]$. Therefore, we assessed generation of intracellular ROS followed by plasma treatment, utilizing distinct fluorescent probes for total ROS and superoxide $\left(\mathrm{O}_{2}^{-}\right)$. Indeed, NTP triggered a time- (Fig. 2B, C) and dose-dependent (Fig. 3A, 
Fig. 1. NTP treatment demonstrates anti-proliferative activity against hepatic tumour cells. (A) Cell viability of Huh7 and HepG2 was analysed by WST- 1 assay $24 \mathrm{~h}$ post plasma treatment. The data were normalized to control values (no exposure), which were set as $100 \%$ cell viability. Readings were done in quadruplicates, data are present as mean $\pm \mathrm{SEM}, \mathrm{n}=3$ (three independent experiments). One-way ANOVA with Newman-Keuls multiple comparison test was used; $\mathrm{t}=0$ time point serving as control; ${ }^{*} \mathrm{P}<0.05,{ }^{* * *} \mathrm{P}<0.001$. (B) Comparison of survival rate between Huh7 and HepG2 cell lines 24 and 72 $\mathrm{h}$ post plasma treatment. Data are assessed as in (A); ${ }^{\# \#} \mathrm{P}<0.01,{ }^{* *} \mathrm{P}<$
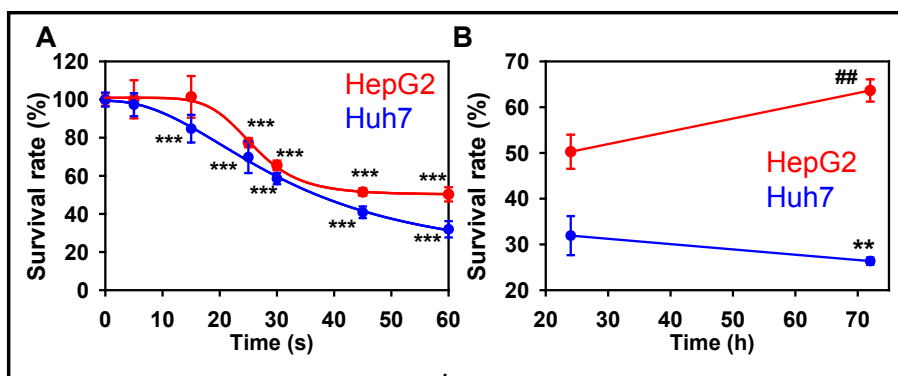

C

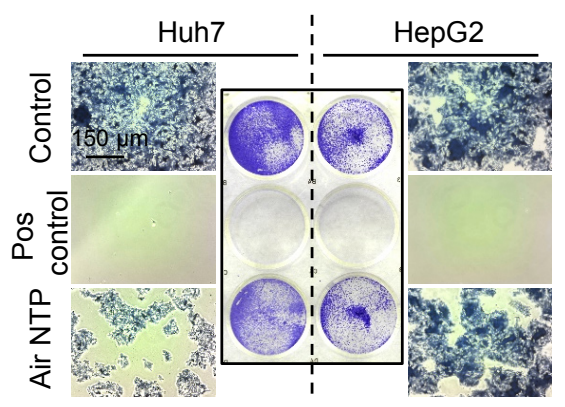
0.01 , comparison 72 vs $24 \mathrm{~h}$ post plasma treatment. (C) The reduced colonogenicity of NTP-treated Huh7 cells. In this experiment the effect of NTP on Huh7 and HepG2 was examined by colony formation assay. Positive control $-20 \%$ ethanol for $60 \mathrm{~min}$.
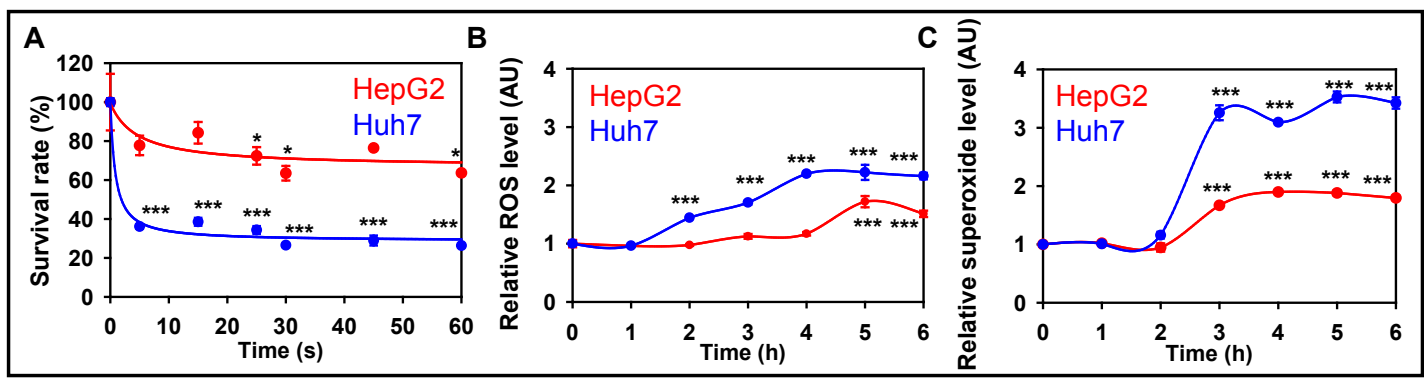

Fig. 2. NTP induces ROS production in HCC cell lines. (A) Cell viability of Huh7 and HepG2 was analysed by WST-1 assay $72 \mathrm{~h}$ post plasma treatment. The data were normalized to control values (no exposure), which were set as $100 \%$ cell viability. Readings were done in quadruplicates, data are present as mean \pm SEM, $n=3$ (three independent experiments). One-way ANOVA with Newman-Keuls multiple comparison test was used; $\mathrm{t}=0$ time point serving as control; ${ }^{*} \mathrm{P}<0.05$, ${ }^{* * *} \mathrm{P}<0.001$. (B) Time-dependent ROS/RNS (after 60s NTP) induction by NTP. Huh7 and HepG2 cells were exposed to NTP, followed by ROS measuring, using the cellular ROS/RNS detection kit (Abcam) by spectrofluorometry. Readings were done in quadruplicates, data are present as mean \pm SEM, $n=3$ (three independent experiments). One-way ANOVA with NewmanKeuls multiple comparison test was used; $\mathrm{t}=0$ time point serving as control, ${ }^{* * *} \mathrm{P}<0.001$. (C) Timedependent (after 60s NTP) Superoxide $\left(\mathrm{O}_{2}{ }^{-}\right)$induction by NTP. Huh7 and HepG2 cells were exposed to NTP, followed by superoxide measuring, using the cellular ROS/Superoxide Detection Assay Kit (Abcam) by spectrofluorometry. Readings were done in quadruplicates, data are present as mean \pm SEM, $n=3$ (three independent experiments). One-way ANOVA with Newman-Keuls multiple comparison test was used; $t=0$ time point serving as control, ${ }^{* * *} \mathrm{P}<0.001$.

B) intracellular ROS and superoxide accumulation in both cell lines. Consistent with the cytotoxicity data, ROS accumulation induced by NTP was significantly greater in Huh7 than in HepG2 cells (Fig. 3A-C).

Mounting evidence suggest that necrosis and apoptosis can be regulated by the formation of specific ROS [51, 52]. Furthermore, ROS overall concentration at steady-state levels, their site of generation and spatial confinement within the cell might determine different 


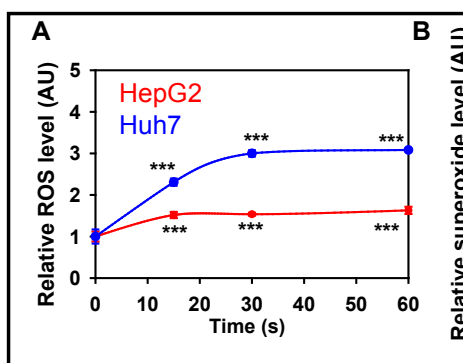

C

C

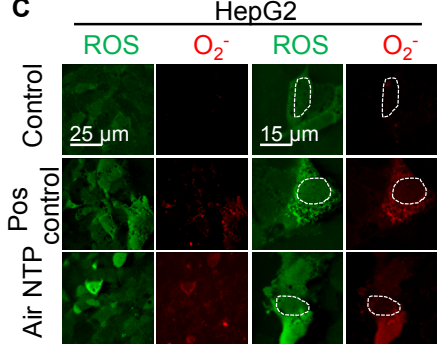

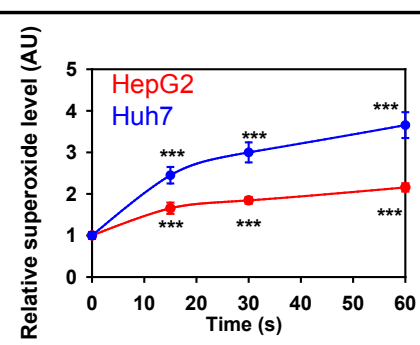

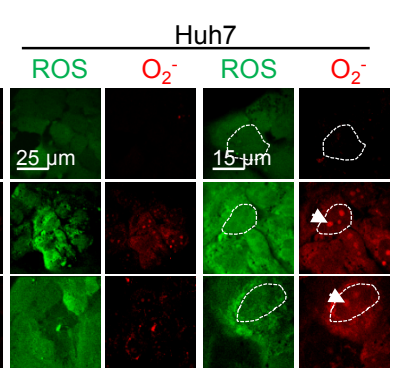

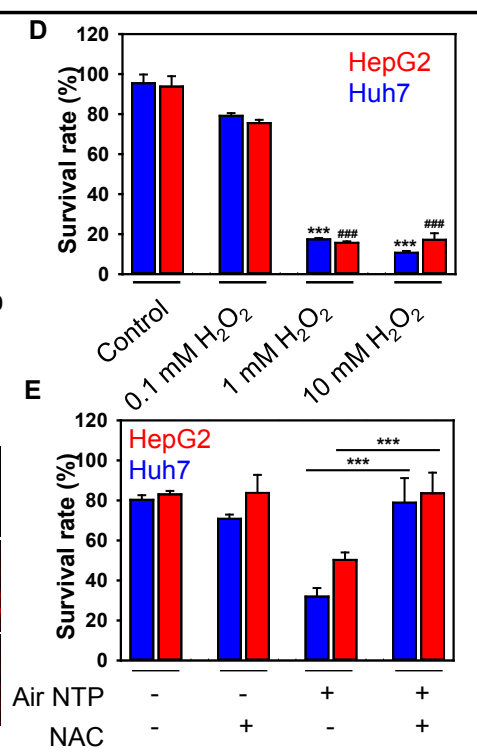

Fig. 3. NTP induces excessive ROS accumulation in HCC cell lines. (A) Dose-dependent (6 hours after NTP exposition) ROS/RNS induction by NTP. Huh7 and HepG2 cells were exposed to NTP, followed by ROS measuring, using the cellular ROS/RNS detection kit (Abcam) by spectrofluorometry. Readings were done in quadruplicates, data are present as mean $\pm S E M, n=3$ (three independent experiments). One-way ANOVA with Newman-Keuls multiple comparison test was used; $t=0$ time point serving as control, ${ }^{* * *} \mathrm{P}<0.001$. (B) Dose-dependent (6 hours after NTP exposition) Superoxide $\left(\mathrm{O}_{2}{ }^{-}\right)$induction by NTP. Huh7 and HepG2 cells were exposed to NTP, followed by superoxide measuring, using the cellular ROS/Superoxide Detection Assay Kit (Abcam) by spectrofluorometry. Readings were done in quadruplicates, data are present as mean \pm SEM, $\mathrm{n}=3$ (three independent experiments). One-way ANOVA with Newman-Keuls multiple comparison test was used; $\mathrm{t}=0$ time point serving as control, ${ }^{* * *} \mathrm{P}<0.001$. (C) NTP treatment induced intracellular ROS / Superoxide $\left(\mathrm{O}_{2}^{-}\right)$production and different subcellular accumulation. Plasma-treated cells were stained with ROS/Superoxide Detection Assay Kit and imaged by confocal microscopy. Representative images out of three independent experiments are shown. Positive control $500 \mu \mathrm{M} \mathrm{H}_{2} \mathrm{O}_{2}$ for $1 \mathrm{~h}$ was used. Circles indicate nucleus borders. Arrows show nuclear localization of superoxide. (D) Effects of $\mathrm{H}_{2} \mathrm{O}_{2}$ on cell viability were detected by WST- 1 assay. Cells were incubated with different concentrations of $\mathrm{H}_{2} \mathrm{O}_{2}$ for $24 \mathrm{~h}$ and then the viability was assessed as in (A). Data are present as mean \pm SEM, $n=3$ (three independent experiments). One-way

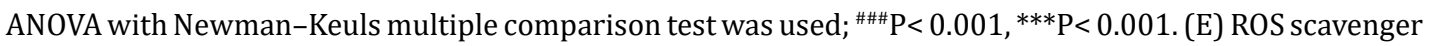
prevents the cytotoxicity induced by NTP. Treatment with ROS scavenging agent N-acetyl-L-cysteine (NAC) completely abolished the cytotoxicity of NTP. Viability of Huh7 and HepG2 cells exposed to the NTP for 60 $\mathrm{s}$ with supplementation of $5 \mathrm{mM}$ NAC was detected by WST- 1 assay $24 \mathrm{~h}$ post plasma treatment. The data were normalized to control values (no exposure), which were set as $100 \%$ cell viability. Readings were done in quadruplicates, data are present as mean $\pm S E M, n=3$ (three independent experiments). One-way ANOVA with Newman-Keuls multiple comparison test was used; ${ }^{* * *} \mathrm{P}<0.001$.

cellular outcomes [51-53]. Indeed, nuclear accumulation of the superoxide anion triggered by NTP was significantly higher in Huh7 cells compared to HepG2 (Fig. 3C). Additionally, we focused on cytotoxicity induced by hydrogen peroxide as one of the major long-lived species detected in plasma [20,22]. Hydrogen peroxide concentrations were selected to be physiologically relevant. It was deliberately shown that concentrations of $\mathrm{H}_{2} \mathrm{O}_{2}(0.1-10 \mathrm{mM})$ are produced in liquids by NTP treatment of physiological solutions [22]. Indeed, we found no differential cytotoxic effect on Huh7 and HepG2 cells upon $\mathrm{H}_{2} \mathrm{O}_{2}$ treatment (Fig. 3D). This finding indicates that NTP and $\mathrm{H}_{2} \mathrm{O}_{2}$ trigger redox signalling differently. To confirm the role of ROS in NTP-induced cell death, we treated both cell lines with $\mathrm{N}$-acetyl-L-cysteine (NAC, a potent ROS scavenger) that completely abolished the cytotoxic effects of NTP (Fig. 3E). 


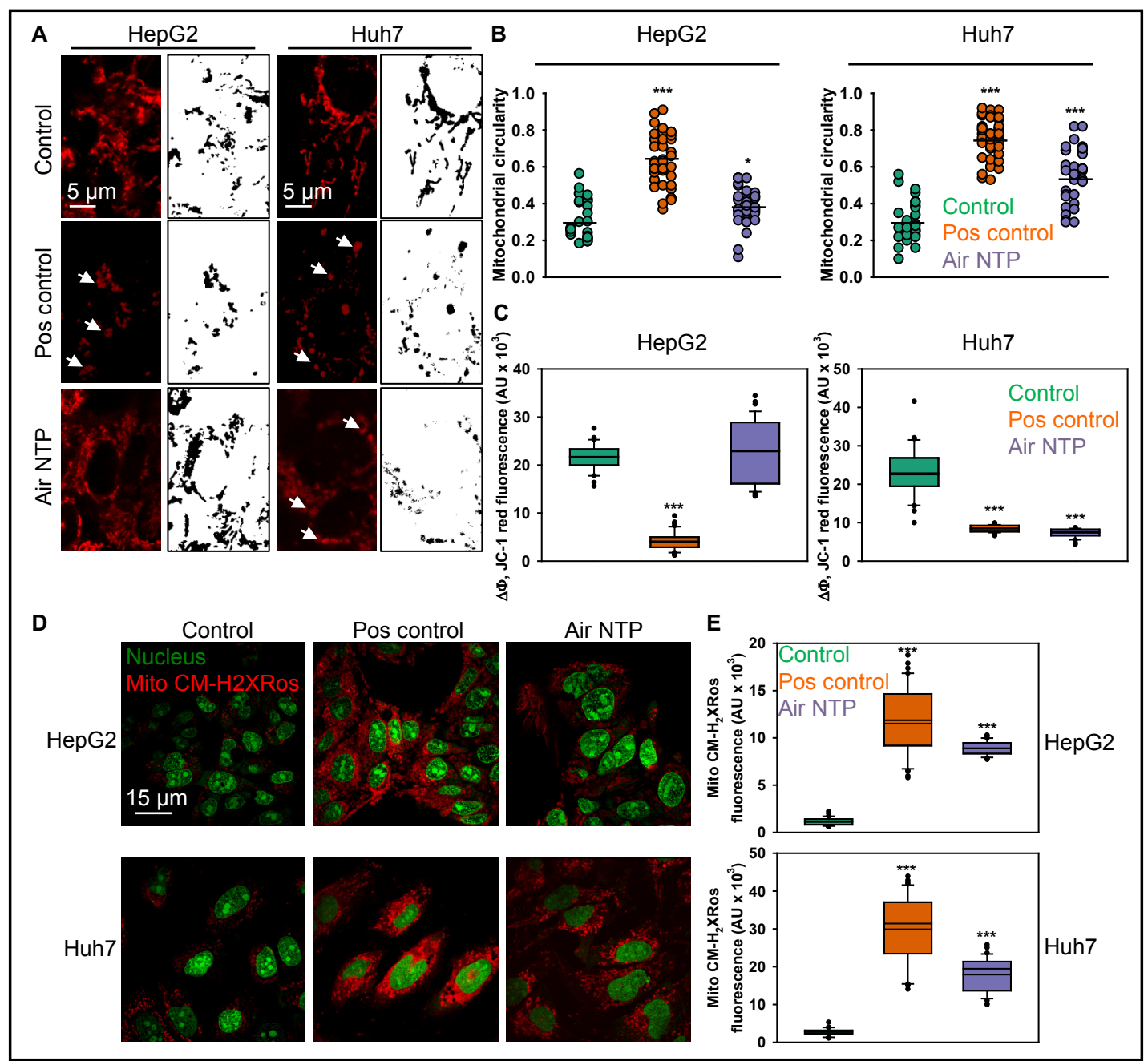

Fig. 4. Alteration of mitochondrial dynamics and induction of mitochondrial membrane depolarization by NTP treatment. (A) Confocal imaging with binarized pictures of the original images shows mitochondrial fragmentation in Huh7 cells treated with NTP for controls stained with JC-1 (1 $\mu \mathrm{M})$. Cells were treated with NTP for $60 \mathrm{~s}$ and stained $5 \mathrm{~h}$ post plasma treatment. Positive control - $20 \%$ ethanol for $20 \mathrm{~min}$. Arrows indicate swollen mitochondrial phenotype. (B) Pre-processed images of mitochondria stained with JC-1 as described in (A) were subjected to morphometric analysis for mitochondrial circularity. Morphometric analysis was performed using Image $(\mathrm{NIH})$. The data expressed as mean of $\mathrm{n}=30-50$ cells; ${ }^{*} \mathrm{P}<0.05$, ${ }^{* * *} \mathrm{P}<$ 0.001. (C) Confocal images of mitochondria stained with JC-1 as described in (A) were quantified for total red JC-1 fluorescence. The red fluorescence intensity of JC-1 reflects the level of $\Delta \mathrm{m} \Phi$. Quantifications performed using Image $(\mathrm{NIH})$ are presented as means of $n=30-50$ cells; ${ }^{* * *} \mathrm{P}<0.001$. (D) Representative confocal analysis of ROS production in HCC cell lines preloaded with the mitochondrial-ROS-sensitive probe MitoTracker $\AA$ red CM-H2XRos under conditions of NTP treatment. Cells were treated with NTP for $60 \mathrm{~s}$ and stained $5 \mathrm{~h}$ post plasma treatment. Non-irradiated cells treated with pyocyanin $(200 \mu \mathrm{M})$ were used as a ROS positive control. For nuclear staining SYTO 13 (green dye) was used. (E) Quantitative imaging analysis of NTP-induced mitochondrial ROS detected by MitoTracker® red CM-H2XRos. Confocal images of mitochondria stained as described in (D) were subjected to fluorescence intensity quantification performed using ImageJ (NIH). The data expressed as mean of $\mathrm{n}=30-50$ cells; ${ }^{* * *} \mathrm{P}<0.001$. 


\section{Cellular Physiology

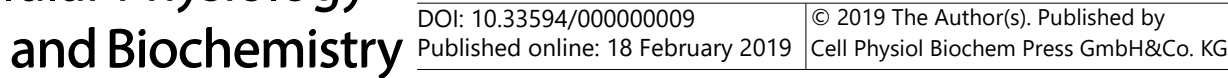

Effects of NTP on mitochondrial dynamics and membrane potential

Nowadays it is widely accepted that mitochondria represent a major source of intracellular ROS (especially hydrogen peroxide and superoxide) generation [54]. The excessive superoxide production results in mitochondrial dysfunction leading finally to cytotoxic effects in cells [54]. It is worth noting, that analysis of the impact of NTP treatment on mitochondrial activity in cancer cells is still fragmented $[29,55,56]$. Furthermore, effects NTP treatment on mitochondria in HCC cell lines have not been elucidated $[46,49,50]$. Therefore, we investigated whether plasma treatment affects mitochondrial function.

We analysed the effect of NTP treatment on the regulation of mitochondrial dynamics by confocal microscopy in HepG2 and Huh7 cells assessing mitochondrial morphology with JC-1 labelling (Fig. 4A). Dysfunction of mitochondria is usually accompanied by mitochondrial fragmentation and fission associated with ROS-induced oxidative stress [57, 58]. We observed a marked increase in mitochondrial fragmentation and swelling in Huh7 cells treated with NTP compared to the controls as revealed by microscopy and quantitative assessment of mitochondrial circularity and area (Fig. 4A, B; and 5A, B). Contrary, treatment of HepG2 with NTP showed negligible effects on mitochondrial morphology and dynamics (Fig. 4A, B; and 5A, B), staying in line with ROS production, cytotoxicity and tumorigenicity data (Fig. 1 and 3). The inhibition of mitochondrial fusion and subsequent mitochondrial fragmentation could be a result of the reduction of mitochondrial membrane potential $(\Delta \mathrm{m} \Phi)$ [59]. We observed the effect of NTP treatment on $\Delta \mathrm{m} \Phi$ by measuring the lipophilic cationic probe JC-1 fluorescent intensity of retained JC- 1 red aggregates as an indication of changes

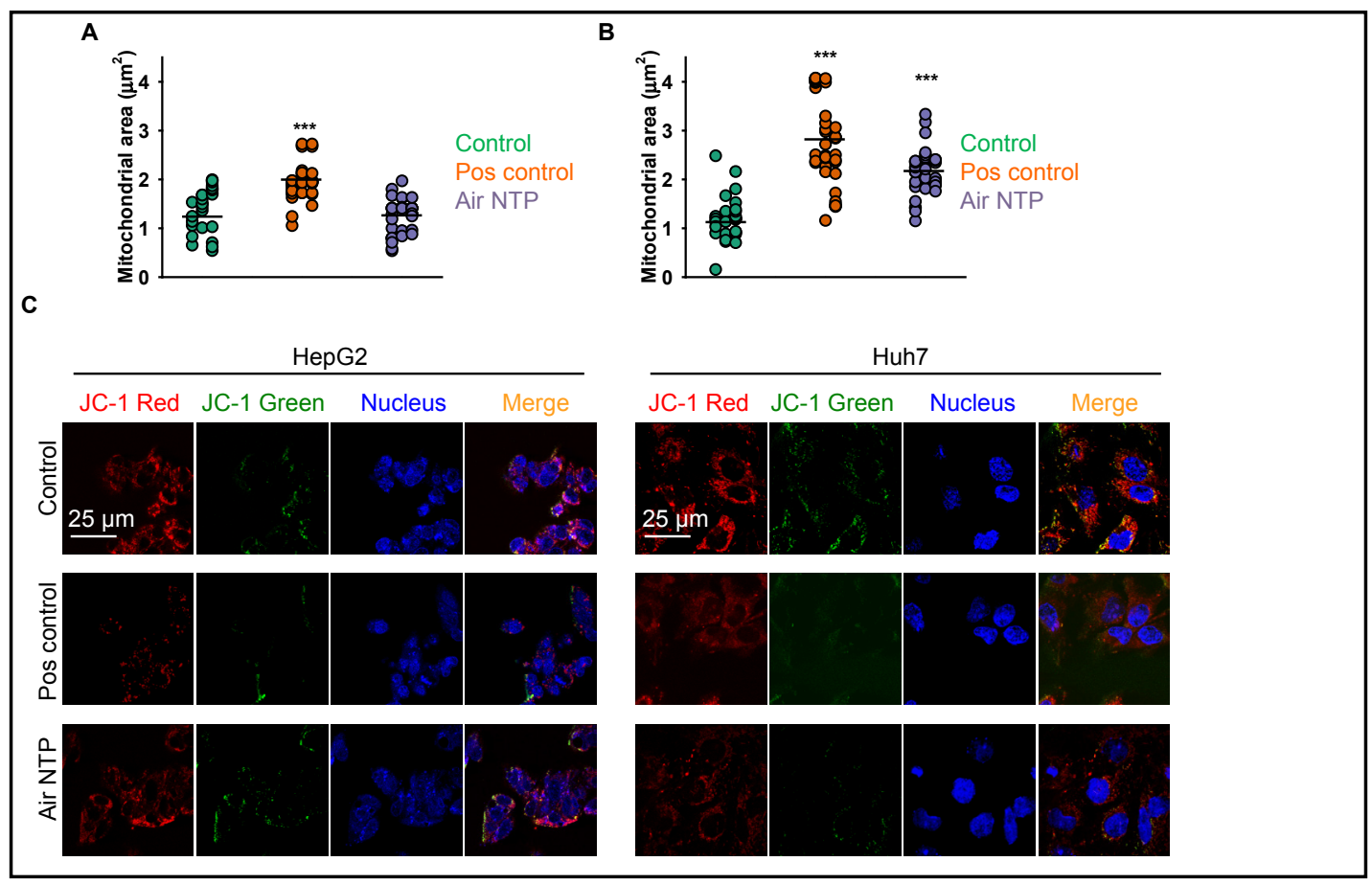

Fig. 5. Alteration of mitochondrial dynamics and induction of mitochondrial membrane depolarization by NTP treatment. HepG2 (A) and Huh7 (B) cells were treated with NTP for 60 s and stained with JC-1 (1 $\mu$ M) 5 $\mathrm{h}$ post plasma treatment. Positive control - $20 \%$ ethanol for $20 \mathrm{~min}$. Pre-processed images of mitochondria stained with JC-1 as described in (Fig. 2A) were subjected to morphometric analysis for mitochondrial area. Morphometric analysis was performed using Image (NIH). The data expressed as "Mean mitochondrial area $\left(\mu \mathrm{m}^{2}\right)^{\prime \prime}, \mathrm{n}=30-50$ cells; ${ }^{* * *} \mathrm{P}<0.001$. (C) Analysis of mitochondrial membrane potential in NTP-treated HepG2 and Huh7 cells. Cells were stained with $1 \mu \mathrm{M}$ JC-1 probe $5 \mathrm{~h}$ post plasma treatment, the JC-1 fluorescence was measured using confocal microscopy. Representative images out of four independent experiments are shown. Positive control - $20 \%$ ethanol for 20 min. Nuclei were labelled with NucRed® Live nuclear stain (blue). 


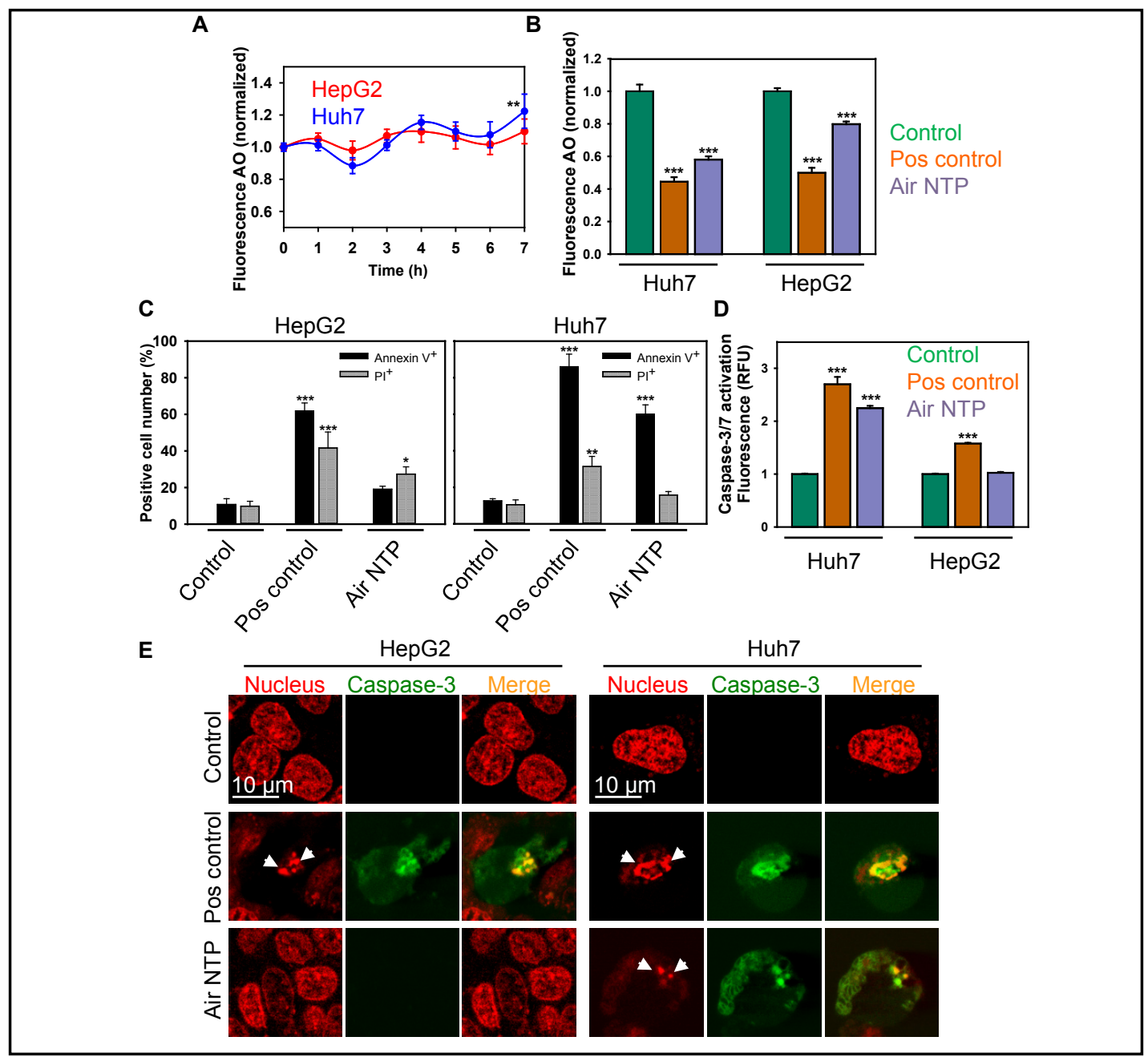

Fig. 6. Analysis of apoptosis hallmarks after NTP treatment. (A) Time-dependent and (B) long-term (8.5h post treatment) effects of NTP on lysosomal integrity. After plasma treatment (60 s) HepG2 and Huh7 cells were stained with acridine orange (AO). AO uptake in acidic lysosomes leads to red fluorescence, which dissipates when the dye leaves this compartment. The accompanying decrease in fluorescence intensity was analysed by spectrofluorometry. Readings were done in quadruplicates. As a positive control, cells were treated with $20 \%$ ethanol for $30 \mathrm{~min}$. The data present the mean values of four independent experiments. Data are expressed as means \pm SEM $(n=4) ;{ }^{* *} \mathrm{P}<0.01,{ }^{* * *} \mathrm{P}<0.001$. (C) Annexin V and propidium iodide (PI) quantification of plasma-treated Huh7 and HepG2. Cells were treated with NTP for $60 \mathrm{~s}$, then $6 \mathrm{~h}$ after the treatment cells were labelled with Hoechst nuclear stain, annexin V and propidium iodide. Labelled cells were imaged with fluorescence microscopy. Annexin V and PI values were analysed with ImageJ (NIH). The data present mean values of five independent experiments. In each experiment 5 randomly selected fields for each sample were quantified. Data are expressed as means \pm SEM $(\mathrm{n}=5) ;{ }^{*} \mathrm{P}<0.05,{ }^{* *} \mathrm{P}<0.01,{ }^{* * *} \mathrm{P}<0.001$. Positive control $-2 \mu \mathrm{M}$ staurosporine for $4 \mathrm{~h}$. (D) Caspase-3/7 activation assay in Huh7 and HepG2. Cells were stimulated with NTP for $60 \mathrm{~s}$, then $6 \mathrm{~h}$ after the treatment cells were labelled CellEvent ${ }^{\mathrm{TM}}$ Caspase-3/7 Green Assay Kit. Following staining, cells were analysed using a fluorescent microplate reader. Readings were done in quadruplicates. As a positive control, cells were treated with $2 \mu \mathrm{M}$ staurosporine for $4 \mathrm{~h}$. The data present the mean values of four independent experiments. Data are expressed as means \pm SEM $(n=4)$; *** $\mathrm{P}<0.001$. (E) Caspase-3/7 activation assay and nuclear fragmentation in Huh7 and HepG2. Cells were stimulated and labelled as in (D). Following staining, labelled cells were imaged with confocal microscopy. Representative images out of three independent experiments are shown. NucRed ${ }^{\mathrm{TM}}$ Live 647 ReadyProbes $^{\mathrm{TM}}$ Reagent (red dye) was used for nucleus labelling. Positive control - $2 \mu \mathrm{M}$ staurosporine for $4 \mathrm{~h}$. White arrows indicate fragmented nuclei. 


\section{Cellular Physiology \\ \begin{tabular}{ll|l} 
and Biochemistry & $\begin{array}{l}\text { DOl: 10.33594/000000009 } \\
\text { Published online: } 18 \text { February } 2019\end{array}$ & $\begin{array}{l}\text { C } 2019 \text { The Author(s). Published by } \\
\text { Cell Physiol Biochem Press GmbH\&Co. KG }\end{array}$ \\
\cline { 2 - 3 }
\end{tabular}

in mitochondrial membrane potential. Treatment of Huh7 cells with NTP induced a lower $\Delta \mathrm{m} \Phi$ compared with the control group, while no significant difference was found between NTP-treated and untreated HepG2 cells (Fig. 4C; and 5C). Mitochondria are known to be one of the main cell sources of ROS. Thus, using the mitochondria-specific probe MitoTracker ${ }^{\circledR}$ red CM- $\mathrm{H}_{2}$ XRos we observed an increased ROS production in both cell lines treated with NTP (Fig. 4D, E). However, NTP induced substantially more mitochondria related ROS in Huh7 comparing to HepG2 cells (Fig. 4D, E).

It is worth noting, that generation of oxidants by mitochondria can be associated with lysosomal rupture and release of lysosomal enzymes [60]. Thus, we analysed the influence of NTP on lysosomal integrity and possible lysosomal leakage using lysomotropic dye acridine orange (AO). Indeed, the analysis showed no significant effects on lysosomal integrity in both cell lines up to $6 \mathrm{~h}$ post plasma treatment (Fig. 6A), the time point when mitochondria damage occurs. Interestingly, $8.5 \mathrm{~h}$ post treatment we observed a decrease in AO red fluorescence in NTP-treated both cell lines (Fig. 6B). NTP-induced lysosomal leakage was substantially more profound in Huh7 comparing to HepG2 cells (Fig. 6B). The timing of lysosomal leakage indicates that lysosomal damage is a secondary event of NTP treatment.

Taking together, all this data point toward mitochondria as a primary effector in plasmatriggered cell death in Huh7 and cell survival in HepG2.

\section{NTP induces apoptosis in Huh7 and Alexander cells}

It becomes evident that mitochondrial fission accompanied with long-lasting or permanent $\Delta \mathrm{m} \Phi$ dissipation may facilitate apoptosis during high levels of cellular stress [58]. Exposure of Huh7 to NTP induced early signs of apoptosis, as measured by binding of Alexa Fluor $^{\text {TM }} 488$-labelled annexin $V$ without any concomitant increase in membrane permeability as shown by propidium iodide exclusion (Fig. 6C; and 7A). By contrast, exposure of HepG2 to NTP led to appearance only small cell fraction having propidium iodide incorporated into the cell nucleus, indicating either a late stage of apoptotic cell death or necrosis (Fig. 6C; and 7A). Caspase 3/7 are effector caspases that are activated by apoptogenic factors released from the mitochondria during oxidative damage. Fluorometric analysis of caspase 3 activation in cells treated with NTP showed that NTP induced apoptosis in Huh7 cells (Fig. 6D). Consistent with the cytotoxicity data and annexin V/PI assay, the caspase 3 activation was not detected in HepG2 irradiated with NTP (Fig. 6D). Confocal microscopy imaging using a novel fluorogenic substrate for activated caspase-3/7, namely CellEvent ${ }^{\mathrm{TM}}$ Caspase-3/7 Green Detection Reagent, confirmed the caspase-3/7 activation in Huh7 induced by NTP (Fig. $6 \mathrm{E}$; and 7B). The reagent consists of four-amino acid peptide (DEVD, specific to cleavage site for caspase-3/7) conjugated to a nucleic acid-binding dye. In apoptotic cells upon caspase $3 / 7$ cleavage of the DEVD peptide, the dye binds to DNA and produces a bright fluorogenic response. This is very robust assay since wash steps are not necessary for detection, when fragile apoptotic cells could be easily lost. Interestingly, we also observed changes in shape of nucleus after NTP treatment in Huh7, namely the irreversible condensation of chromatin and fragmented nucleus (Fig. 6E; and 7B), which are typical for apoptosis [61].

To analyse NTP effects in liver cancer cells we challenged with NTP another cell line, namely Alexander cells. Indeed, NTP did significantly affect the viability of Alexander cells within the first $24 \mathrm{~h}$ post exposure (Fig. 8A). Consistent with Huh7, NTP induced expression of annexin $\mathrm{V}$ on Alexander membrane prior to the increase of the cell membrane permeability (Fig. 8B; and Fig. 9). The caspase 3 activation assay (Fig. 8C) confirmed apoptotic cell death triggered by NTP in Alexander cells.

\section{NTP induces Huh7 apoptosis via p53 signalling cascade}

It is well-established that the tumour suppressor p53 protein activates cell death programs through multiple pathways [62]. On the other hand, p53 mutations in human tumours contribute to resistance to commonly used chemotherapeutic agents [47]. Moreover, targeted inhibition of mutant p53 expression has emerged as promising therapeutic strategy [63]. 
It is known that Huh7 and Alexander cells display a p53 mutation, in contrast to HepG2 cell line displaying wild type p53 [64]. P53 may directly induce apoptosis in response to stress via interactions with Bcl-2 family members [65]. HepG2 cells, bearing high levels of Bcl-2, are resistant to cell death activation via ROS accumulation [66]. Taking these facts together with our findings on differential effects of NTP on cytotoxicity and apoptosis induction in Huh7 and Alexander versus HepG2 cells, we hypothesized that differential effects of NTP in those cell lines are mediated via p53-Blc-2 signalling interplay.

Indeed, we found that NTP induced p53 downregulation in Huh7 as shown by immunoblot analysis (Fig. 10A). Contrary, p53 was not affected by NTP in HepG2 (Fig. 10A). NTP treatment also resulted in Bcl-2 upregulation in both cell lines (Fig. 10A); however, in HepG2 this upregulation was markedly higher comparing to Huh7 (Fig. 10A).

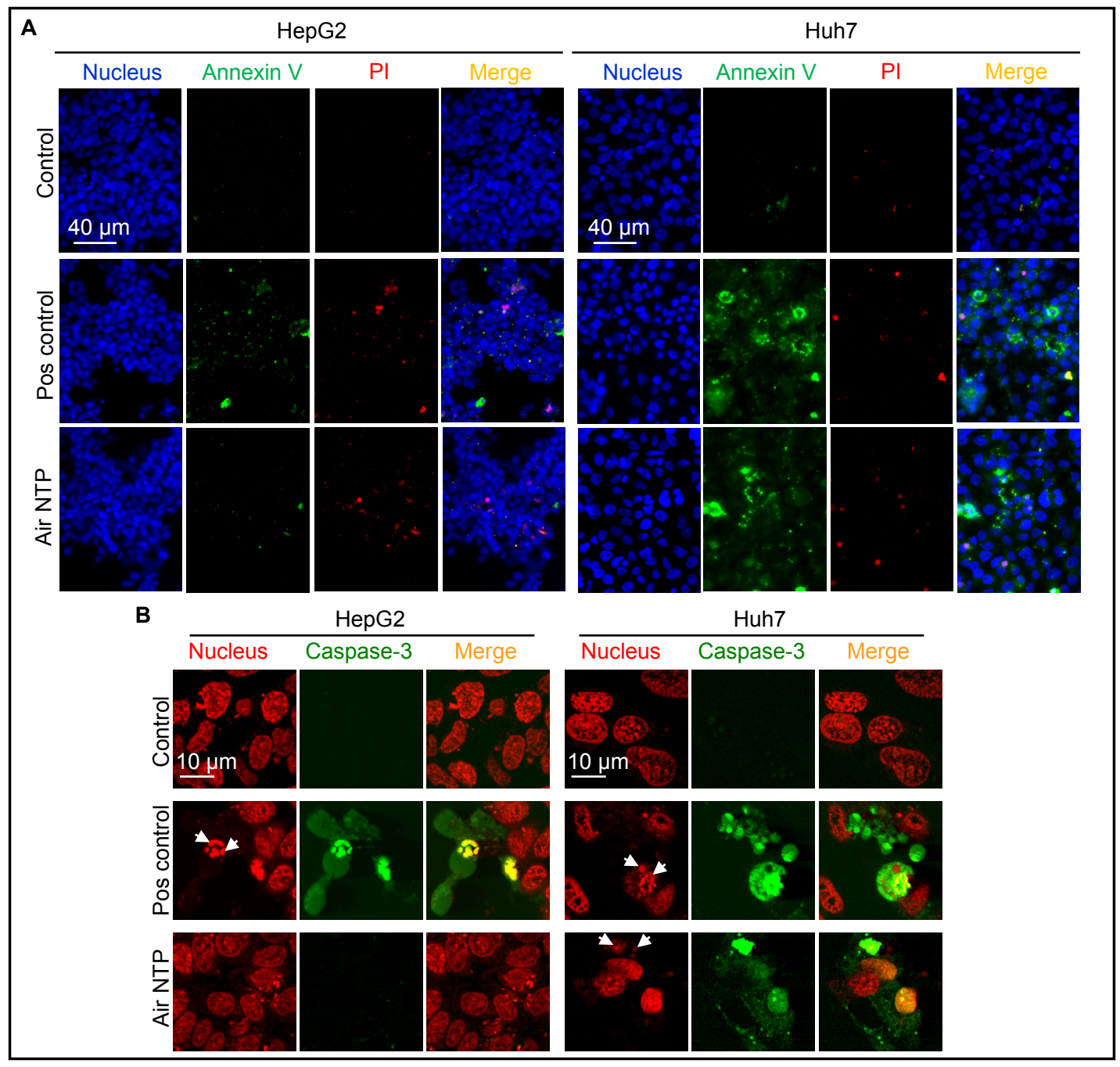

Fig. 7. Microscopy imaging of annexin $V$ and propidium iodide-positive cells after NTP treatment. (A) HepG2 and Huh7 cells were treated with NTP for $60 \mathrm{~s}$, then $6 \mathrm{~h}$ after treatment cells were labelled with Hoechst nuclear stain - blue dye, annexin $\mathrm{V}$ - green dye and propidium iodide - red dye. Labelled cells were imaged with fluorescence microscopy. Representative images out of three independent experiments are shown. Positive control - $2 \mu \mathrm{M}$ staurosporine for $4 \mathrm{~h}$. (B) Caspase-3/7 activation assay in Huh7 and HepG2. Cells were stimulated with NTP for $60 \mathrm{~s}$, then $6 \mathrm{~h}$ after the treatment cells were labelled CellEvent ${ }^{\mathrm{TM}}$ Caspase- $3 / 7$ Green Assay Kit. Following staining, cells were analysed by confocal microscopy. Representative images out of three independent experiments are shown. NucRed ${ }^{\mathrm{TM}}$ Live 647 ReadyProbes $^{\mathrm{TM}}$ Reagent (red dye) was used for nucleus labelling. Positive control $-2 \mu \mathrm{M}$ staurosporine for $4 \mathrm{~h}$. 
Interestingly, $\mathrm{H}_{2} \mathrm{O}_{2}$ treatment lead to p53 downregulation in both Huh7 and HepG2 cells accompanied with the conversion of LC3A/B-I to LC3A/B-II (marker for autophagosomes) as shown by immunoblot analysis whereas NTP treatment showed no effect on LC3 conversion (Fig. 10A). Taken together, $\mathrm{H}_{2} \mathrm{O}_{2}$ induced an autophagic response. Giving that the NTP composition is quite complex (in addition to $\mathrm{H}_{2} \mathrm{O}_{2}$ many kinds of other reactive species are generated in plasma, e.g. $\mathrm{O},{ }^{\circ} \mathrm{OH}, \mathrm{O}_{2}{ }^{--},{ }^{1} \mathrm{O}_{2}, \mathrm{NO}^{*}, \mathrm{NO}_{2}{ }^{2}, \mathrm{H}_{2} \mathrm{O}_{2}, \mathrm{NO}_{2}^{-}, \mathrm{NO}_{3}^{-}, \mathrm{O}_{3}[20,22]$ ), it is not

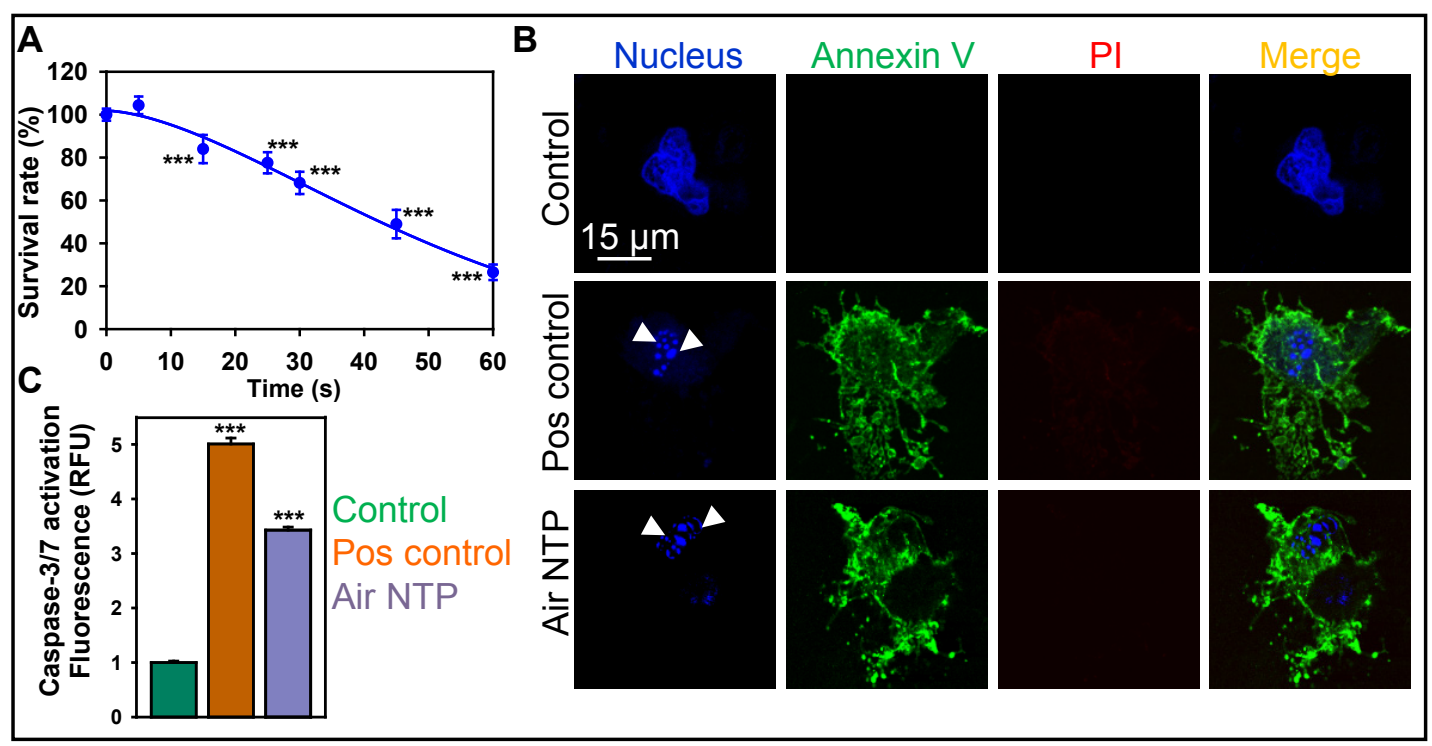

Fig. 8. NTP treatment results in apoptosis of Alexander cells. (A) Analysis of cytotoxicity in Alexander cells treated with NTP. Cell viability was analysed by WST-1 assay $24 \mathrm{~h}$ post plasma treatment. The data were normalized to control values (no exposure), which were set as $100 \%$ cell viability. Readings were done in quadruplicates, data are present as mean $\pm \mathrm{SEM}, \mathrm{n}=3$ (three independent experiments). One-way ANOVA with Newman-Keuls multiple comparison test was used; $\mathrm{t}=0$ time point serving as control; ${ }^{* * *} \mathrm{P}<0.001$. (B) Alexander cells were treated with NTP for $60 \mathrm{~s}$ and then $6 \mathrm{~h}$ after the treatment labelled with NucRed nuclear stain (blue), annexin V (green) and PI (red). Cells treated with $2 \mu \mathrm{M}$ staurosporine for $4 \mathrm{~h}$ served as a positive control. Labelled cells were imaged with confocal microscopy. Representative images out of three independent experiments are shown. White arrows indicate fragmented nuclei. (C) Caspase-3/7 activation assay in Alexander cells. Alexander cells were treated with NTP for $60 \mathrm{~s}$ and then $6 \mathrm{~h}$ after the treatment cells were labelled CellEvent ${ }^{\mathrm{TM}}$ Caspase-3/7 Green Assay Kit. Following staining, cells were analysed using a fluorescent microplate reader. Readings were done in quadruplicates. As a positive control, cells were treated with $2 \mu \mathrm{M}$ staurosporine for $4 \mathrm{~h}$. The data present the mean values of four independent experiments. Data are expressed as means \pm SEM $(n=4) ;{ }^{* * *} P<0.001$.

Fig. 9. Alexander cells were treated with NTP for $60 \mathrm{~s}$ and then $6 \mathrm{~h}$ after treatment cells were labelled with Hoechst nuclear stain - blue dye, annexin $\mathrm{V}$ - green dye and propidium iodide - red dye. Labelled cells were imaged with fluorescence microscopy. Representative images out of three independent experiments are shown. Positive control $-2 \mu \mathrm{M}$ staurosporine for $4 \mathrm{~h}$.

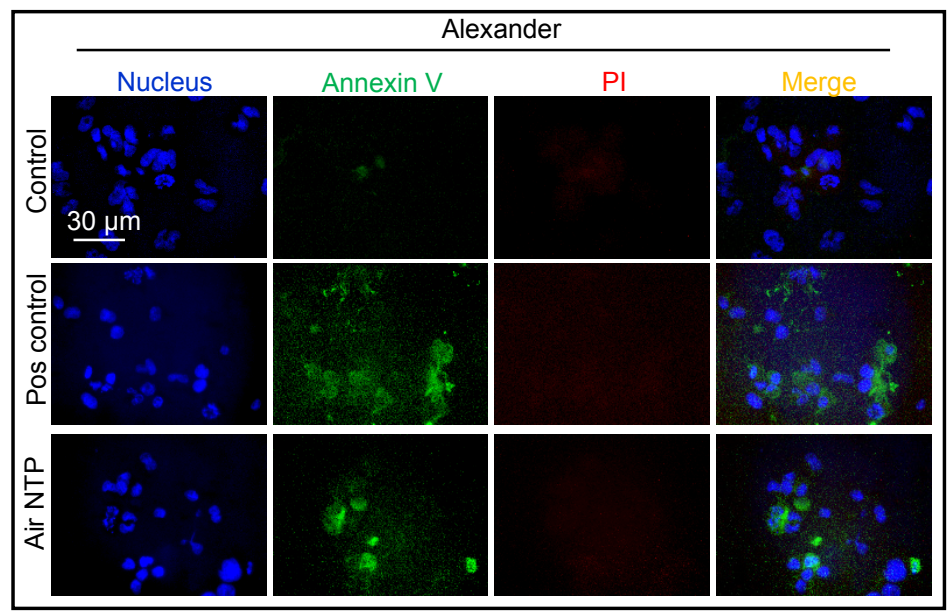




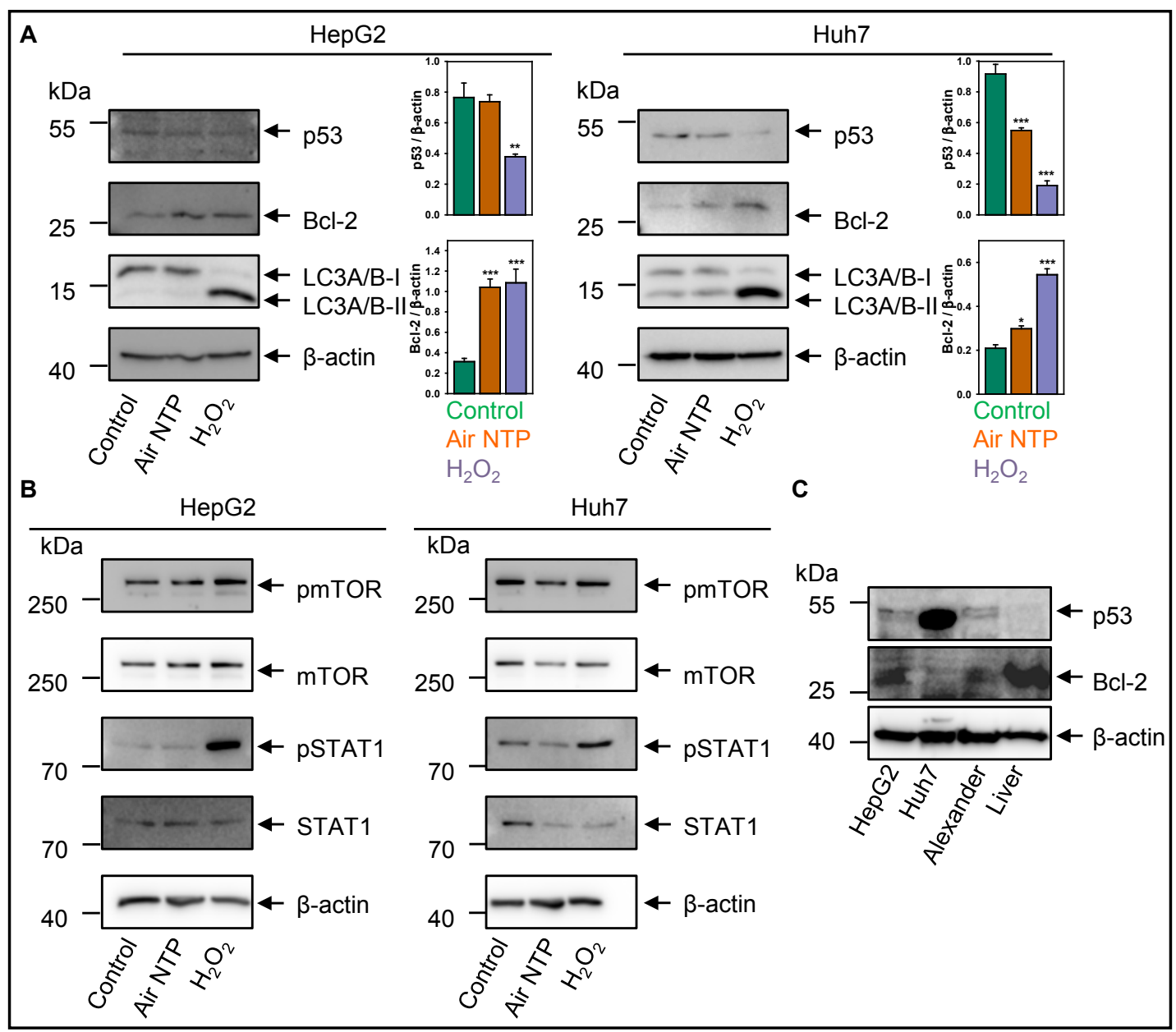

Fig. 10. NTP induces p53 dependant apoptosis in Huh7 cells. (A) NTP treatment induces Bcl-2 upregulation in HepG2 and downregulation of p53 in Huh7 cells. Cells were treated with NTPs for 60 s. Cells were analysed by Western immunoblotting $4 \mathrm{~h}$ after treatment. Actin - control of equal protein loading. The graphs show densitometric quantification of p53 and Bcl-2 Western immunoblots, ${ }^{*} \mathrm{P}<0.05,{ }^{* *} \mathrm{P}<0.01,{ }^{* * *} \mathrm{P}<0.001$, mean $\pm \mathrm{SEM}, \mathrm{n}=3$. Representative blots out of three independent experiments are shown. Non-irradiated cells treated with $\mathrm{H}_{2} \mathrm{O}_{2}(10 \mathrm{mM})$ were used as a positive control (full blots are presented in Appendix A). (B) NTP treatment downregulates phosphorylation of Stat1 in Huh7 cells. Cells were treated as in (A) and analysed by Western immunoblotting $4 \mathrm{~h}$ after treatment. Actin - control of equal protein loading (full blots are presented in Appendix A). (C) Bcl-2 and p53were analysed in whole cell lysates of HepG2, Huh7, Alexander cells, and human liver by immunoblotting; Actin - control of equal protein loading (full blots are presented in Appendix A).

surprising that NTP and $\mathrm{H}_{2} \mathrm{O}_{2}$ trigger distinct signalling pathways. What could then be a key to alleged effects of NTP versus $\mathrm{H}_{2} \mathrm{O}_{2}$ ? This challenging question prompted us to seek a link between p53, autophagy and apoptosis.

Lysosome leakage may trigger cancer cell apoptosis via downregulation of MTORC1 (a multicomponent protein kinase complex that includes mTOR, Regulatory Associated Protein of mTOR (RAPTOR), and mLST8/GßL) [67] in a p53-independent manner [68]. Since neither NTP nor $\mathrm{H}_{2} \mathrm{O}_{2}$ treatment had any effect on mTOR phosphorylation (Fig. 10B), this possibility was ruled out. These results also support our additional finding that NTP treatment of Huh7 leads to p53-dependent apoptosis via downregulation of p53 and STAT1 (Fig. 10A, B), both triggered by mitochondrial dysfunction (Fig. 4). 
Fig. 11. Inhibition of $\mathrm{Bcl}-2$ sensitises resistant HepG2 to NTP induced cell death. (A) Comparison of survival rate between Huh7, HepG2 and Alexander cell lines $24 \mathrm{~h}$ post plasma treatment. Cells were treated with NTP for $60 \mathrm{~s}$ and cell viability was analysed by WST-1 assay. The data were normalized to control values (no exposure), which were set as 100 $\%$ cell viability. Readings were done in quadruplicates, data are present as mean \pm SEM, $n=3$ (three independent experiments). One-way ANOVA with NewmanKeuls multiple comparison test was used; ${ }^{\# \# P}<0.01,{ }^{* *} \mathrm{P}<0.001$.

(B) Bcl-2 inhibition restores NTP

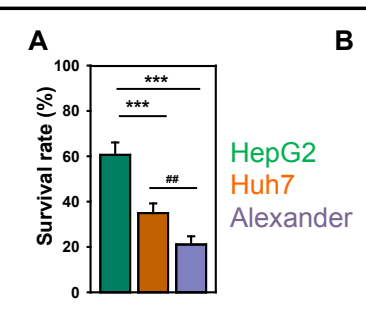

C

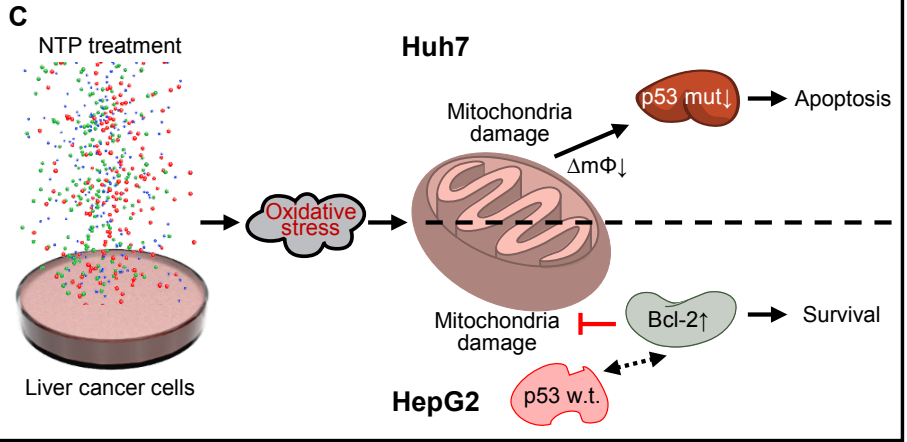

sensitivity in resistant HepG2 cells. Cell viability as detected by the WST-1 assay of HepG2 treated with NTPs for $60 \mathrm{~s}$ with supplementation of 1, 5 or $10 \mu \mathrm{M}$ ABT-737 (selective Bcl-2 inhibitor), measured $24 \mathrm{~h}$ after exposure. Readings were done in quadruplicates, data are present as mean $\pm \mathrm{SEM}, \mathrm{n}=3$ (three independent experiments). One-way ANOVA with Newman-Keuls multiple comparison test was used; ${ }^{\# \# ~} \mathrm{P}<0.001,{ }^{* * *} \mathrm{P}<$ 0.001. (C) Tentative scheme of molecular mechanisms of Huh7 sensitivity and HepG2 resistivity to NTP induced cell death. $\Delta \mathrm{m} \Phi$ - mitochondrial membrane potential.

STAT1 was recognized as a tumour suppressor, although there is increasing evidence indicating its tumour promoting functions [69]. Specifically, induction of STAT1 cooperatively promotes liver damage and fibrosis and may contribute to liver carcinogenesis [70]. Furthermore, high STAT1 levels showed correlation with poor cancer outcomes, whereas high levels of pSTAT1 favoured good prognosis [69]. Inhibitors of STAT signalling showed a strong apoptotic response in HCC cell lines [71]. In our experiments immunoblot analysis revealed upregulated STAT1 phosphorylation only in Huh7 and HepG2 cells treated with hydrogen peroxide (Fig. 10B). Contrary, NTP treatment resulted in a downregulation of both pSTAT1 and STAT1 in Huh7 (Fig. 10B). HepG2 treated with NTP showed no detectable effects on STAT1 (Fig. 10B).

Since p53 is mutated and overexpressed in Huh7 cells [64], p53-dependent apoptosis via downregulation of p53 can be executed in these

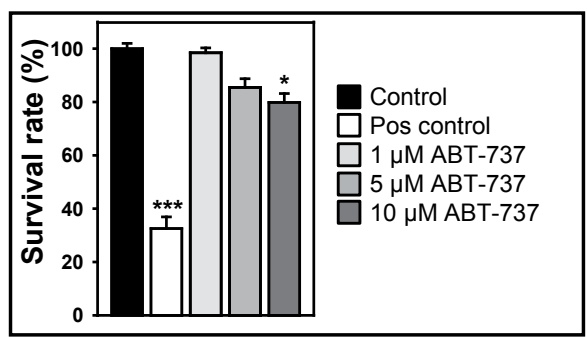

Fig. 12. HepG2 cells were treated with various concentrations of ABT-737 for 24 $h$, and the cell viability was subsequently quantified using the WST- 1 assay. Readings were done in quadruplicates, data are present as mean \pm SEM, $n=3$ (three independent experiments). Positive control - $20 \%$ ethanol for $60 \mathrm{~min}$. One-way ANOVA with Newman-Keuls multiple comparison test was used; ${ }^{*} \mathrm{P}<0.05,{ }^{* * *} \mathrm{P}<0.001$. cells. HepG2 cells display wild type p53 and they have also high levels of Bcl-2 comparing to Huh7 that protects them from induction of apoptosis via oxidative stress [29]. This explains why NTP treatment is less efficient in triggering cell death in HepG2. Indeed, in non-treated cells, immunoblot analysis of Bcl-2 and p53 expression revealed that Huh7 cells have the highest cell content of p53 protein (Fig. 10C), HepG2 express most of the anti-apoptotic Bcl2 comparing to Huh7 and Alexander cells (Fig. 10C). Furthermore, comparative survival analysis of three cell lines treated with NTP showed that Alexander cells were the most sensitive to NTP-induced cell death whereas HepG2 were the most resistant (Fig. 11A). 


\section{Cellular Physiology Cell Physiol Biochem 2019:52:119-140 \\ \begin{tabular}{ll|l} 
and Biochemistry & $\begin{array}{l}\text { DOl: } 10.33594 / 000000009 \\
\text { Published online: } 18 \text { February } 2019\end{array}$ & $\begin{array}{l}\text { C } 2019 \text { The Author(s). Published by } \\
\text { Cell Physiol Biochem Press GmbH\&Co. KG }\end{array}$
\end{tabular} \\ Smolková et al:: Molecular Mechanisms of Non-Thermal Plasma Action on Cancer Cells}

These data confirm that in cells with mutated p53 and low levels of Bcl-2 NTP treatment results in apoptosis.

To confirm cytoprotective role of Bcl-2 in HepG2 against NTP, we run a cytotoxicity analysis in the presence of Bcl-2 pharmacological inhibitor. HepG2 treatment with ABT737 (a potent and selective inhibitor of Bcl-2) alone had minimal cytotoxic effects (Fig. 12). Strikingly, NTP treatment in combination with ABT-737 resulted in dose-dependent cell death in HepG2 (Fig. 11B), confirming the established role of Bcl-2 in inhibition of cell death triggered by NTP via oxidative stress.

\section{Discussion}

Non-thermal plasma (NTP), an interesting new form of physicochemical treatment that alters redox signalling in cells, has emerged recently $[18,19]$. NTP is a partially ionized gas that contains a chemically complex and reactive environment that includes ions, electrons, free radicals, UV radiation, and neutral molecules, for review see [20]. Not surprisingly, a burst of studies has shown a numerous biological and medical applications of NTP. Notwithstanding such extensive research the exact action mechanisms of plasma on biological systems, including cells and humans, are not well understood. Growing number of studies suggests that major factors underlying the effect of plasma-cell interaction are reactive oxygen (ROS) and reactive nitrogen species (RNS) whereas the influence of others (i.e. UV photons, a transient electromagnetic field, and energetic charged particles) is negligible [22, 23, 30,31]. Despite that the accumulation of ROS in cancer cells by NTP is a well-known phenomenon shown previously in an enormous number of studies, rigorous analysis of the time- and dose-dependent kinetics of intracellular ROS and superoxide accumulation has not been performed. Here we show that NTP triggered a time- and dose-dependent intracellular ROS and superoxide accumulation in HCC cell lines. Furthermore, we show for the first time that NTP treatment results in nuclear accumulation of the superoxide anion in Huh7. Hydrogen peroxide $\left(\mathrm{H}_{2} \mathrm{O}_{2}\right.$, one of the major long-lived species detected in plasma [20,22]) is believed to be the major NTP compound that executes cytotoxic effects. However, our findings indicate that redox signalling triggered by NTP is distinct from $\mathrm{H}_{2} \mathrm{O}_{2}$. Taking into account complexity of ROS/RNS chemical composition of NTP, this finding is not a surprise.

Several studies reported on the involvement of mitochondria in plasma-induced cancer cell apoptosis $[29,55,56]$. However, in liver tumour cell lines effects of NTP treatment on mitochondria has not been completely elucidated since combination of different analysis of mitochondria involvement in NTP effects is lacking in papers published to date $[48,59$, 61]. We did not only analyse mitochondrial fission and circularity but we also measured mitochondrial ROS production and assessed mitochondrial size and shape. Our results show that NTP induced substantially more mitochondria related ROS in Huh7 comparing to HepG2 cells.

Furthermore, we identify p53 tumour suppressor protein as cellular NTP-effector in HCC cell lines, which mediates ROS-induced cell death in response to acute NTP treatment. Although some involvement of p53-related pathway was shown previously $[46,59,72]$, those studies do not describe mechanism of NTP action on p53-pathway. First of all, cell lines used in those studies do not overexpress mutated p53. Contrary, we base our conclusion on experiments comparing cell lines bearing wild type p53, mutated p53 and overexpressed mutated p53 (Fig. 10). Secondly, previous studies utilized either helium-oxygen or argon plasma $[46,59,72]$ whereas we used air-based NTP. NTP contains a chemically complex and reactive environment that crucially depends on chemical composition of the carrier gas. We and others have also shown that chemical composition of NTP has strong impact on execution of distinct cell death pathways [19, 26, 28, 30, 32, 56, 73].

Indeed, Huh7 and Alexander cells bear a p53 mutation, whereas HepG2 cell line has a wild type p53 [64]. Wild type p53 induces apoptosis in response to stress via interactions with Bcl-2 family members [65]. However, HepG2 cells show high levels of Bcl-2, thus they 


\section{Cellular Physiology \\ \begin{tabular}{ll|l} 
and Biochemistry & $\begin{array}{l}\text { DOl: 10.33594/000000009 } \\
\text { Published online: } 18 \text { February } 2019\end{array}$ & $\begin{array}{l}\text { C } 2019 \text { The Author(s). Published by } \\
\text { Cell Physiol Biochem Press GmbH\&Co. KG }\end{array}$ \\
\cline { 2 - 3 }
\end{tabular} \\ Smolková et al.: Molecular Mechanisms of Non-Thermal Plasma Action on Cancer Cells}

are resistant to cell death activation via ROS accumulation [66]. Taking these facts together with our findings, we revealed that differential effects of NTP in those cell lines are mediated via p53-Blc-2 signalling interplay. NTP treatment of Huh7 leads to p53-dependent apoptosis via concomitant downregulation of p53 and STAT1 (Fig. 10A, B) triggered by mitochondrial dysfunction (Fig. 4). Such signalling is possible due to the fact that Huh7 cells possess p53 mutation [64]. In contrast, HepG2 cells display wild type p53, however, have high levels of Bcl-2 comparing to Huh7 that protect against induction of apoptosis via oxidative stress [29]. Thus, it is understandable why NTP treatment is less efficient in triggering cell death in HepG2. Indeed, immunoblot analysis of Bcl-2 and p53 expression in different cell lines revealed that Huh7 cells bear the highest amount of p53 (Fig. 10C). However, HepG2 expressed more antiapoptotic Bcl-2 comparing to Huh7 and Alexander (Fig. 10C). Comparative survival analysis of three cell lines showed that Alexander cells were the most sensitive to NTP-induced cell death whereas HepG2 were the most resistant (Fig. 11A). These data clearly show that in cells with mutated p53 and low levels of Bcl-2 NTP treatment results in apoptosis.

It is worth noting here, that we do not simply show involvement of p53 in NTP-triggered cell death, but also we decouple interplay between STAT1 and p53-signalling pathways in NTP-induced apoptosis (Fig. 10). STAT1 has been shown to support invasion of tumour cells harbouring mutated p53 [60]. Additionally, STAT1 activation has been involved in cancer progression [69]. Thus, inhibitors of STAT signalling in HCC cell lines represent a strategy to induce apoptotic response [71]. Here we show that NTP treatment resulted in a downregulation of both pSTAT1 and STAT1 in Huh7. STAT1 in HepG2 was not affected by treated with NTP (Fig. 10). Importantly, both Huh7 and HepG2 cells treated with hydrogen peroxide had an upregulated STAT1 phosphorylation. Moreover, $\mathrm{H}_{2} \mathrm{O}_{2}$ treatment of both cell lines lead to p53 downregulation accompanied with the conversion of LC3A/B-I to LC3A/BII. Taking together these data strongly suggest that hydrogen peroxide induced autohpagic cell death in both Huh7 and HepG2 cells. Contrary, NTP induced p53 dependant apoptosis in Huh7 cells. First of all, NTP induced mitochondrial destabilization and production of mitochondrial ROS (Fig. 4) prior lysosomal rupture (Fig. 6A, B) in Huh7 cells. Secondly, NTP treatment of Huh7 resulted in simultaneous downregulation of p53, pSTAT1 and STAT1 (Fig. 10). Thirdly, extent of resulted cell death was proportional to the expression degree of mutated form of p53 (Fig. 11A). Importantly, recent finding indicate that STAT1 supports growth of tumour cells harbouring mutated p53 [60,69]. Thus, simultaneous inhibition of STAT1 and mutated p53 could be a potential therapeutic strategy.

Bcl-2 has been shown to be down-regulated by NTP in cancer cells [61, 74]. However, there is no comparison with cell line overexpressing Bcl-2 presented in those studies. Additionally, the authors performed only mRNA expression analysis and immunoblot of Bcl2 protein whereas no inhibition assay was run and no functionally linked data confirming Bcl-2 involvement in cell death or survival were obtained. Our data demonstrate the pivotal role of Bcl-2 in inhibition of cell death triggered by NTP via oxidative stress. Indeed, HepG2 expressed more anti-apoptotic Bcl-2 comparing to Huh7 and Alexander. Comparative survival analysis of three cell lines treated with NTP showed that HepG2 were the most resistant to NTP-induced cell death. Additionally, by blocking Bcl-2 activity using specific pharmacological inhibitor we sensitized HepG2 to NTP-induced cell death.

\section{Conclusion}

In summary, we show that NTP treatment results in cytotoxicity of Huh7 cell line inducing apoptosis through the accumulation of ROS and subsequent p53 signalling. This apoptosis induction is inhibited in HepG2 due to high levels of Bcl-2 expression (Fig. 11C). The cytotoxicity of NTP depends on expression of Bcl-2 and p53 and can be inhibited by addition of ROS scavengers. Our results shed more light on the identification of molecular targets upon NTP treatment of liver cancer cells. Moreover, we present here NTP as a 


\section{Cellular Physiology Cell Physiol Biochem 2019:52:119-140 \\ \begin{tabular}{l|l|l}
\hline DOI: 10.33594/000000009 & ( 2019 The Author(s). Published by
\end{tabular} \\ Published online: 18 February 2019 Cell Physiol Biochem Press GmbH\&Co. KG \\ Smolková et al.: Molecular Mechanisms of Non-Thermal Plasma Action on Cancer Cells}

physicochemical cue for targeted manipulation of redox signalling in the absence of other activators.

Air NTP induces profound accumulation of ROS in liver cancer cells. This was thoroughly documented by time- and dose-dependent kinetics of ROS accumulation in HCC cells. Furthermore, we recorded nuclear compartmentalization of the superoxide anion triggered by NTP. NTP treatment also resulted in dysfunction of mitochondria in Huh7 cells accompanied by mitochondrial fragmentation and fission that was associated with ROS-induced oxidative stress. Overall, NTP induced apoptotic death in Huh7 and Alexander liver cancer cells whereas HepG2 showed resistance to NTP due to the Bcl-2 protein overexpression. Air NTP treatment resulted in simultaneous downregulation of mutated p53, pSTAT1 and STAT1. In combination with mitochondrial dysfunction the latter results in execution of p53-dependant apoptosis. This suggests that mutated p53 might be a potential cellular NTP-effector in HCC cell lines. Contrary to NTP, sole $\mathrm{H}_{2} \mathrm{O}_{2}$ treatment of both cell lines induced autohpagic cell death.

\section{Acknowledgements}

The authors acknowledge the J.E. Purkyně fellowship awarded by the Academy of Sciences of the Czech Republic, and MH CZ - DRO Institute for Clinical and Experimental Medicine - IKEM, IN 00023001. The work is supported by Operational Programme Research, Development and Education financed by European Structural and Investment Funds and the Czech Ministry of Education, Youth and Sports (Project No. SOLID21 - CZ.02.1.01/0.0/0.0/1 6_019/0000760), project FV10081 of MPO and "Program podpory perspektivních lidských zdrojů - Mzdová podpora postdoktorandů na pracovištích AV ČR”.

\section{Disclosure Statement}

The authors do not have financial interests or conflicts.

\section{References}

- 1 Maluccio M, Covey A: Recent progress in understanding, diagnosing, and treating hepatocellular carcinoma. CA Cancer J Clin 2012;62:394-399.

- 2 Llovet JM, Villanueva A, Lachenmayer A, Finn RS: Advances in targeted therapies for hepatocellular carcinoma in the genomic era. Nat Rev Clin Oncol 2015;12:408-424.

- 3 Lozano R, Naghavi M, Foreman K, Lim S, Shibuya K, Aboyans V, Abraham J, Adair T, Aggarwal R, Ahn SY, Alvarado M, Anderson HR, Anderson LM, Andrews KG, Atkinson C, Baddour LM, Barker-Collo S, Bartels DH, Bell ML: Global and regional mortality from 235 causes of death for 20 age groups in 1990 and 2010: a systematic analysis for the Global Burden of Disease Study 2010. Lancet 2012;380:2095-2128.

- 4 Siegel RL, Miller KD, Jemal A: Cancer statistics, 2018. CA Cancer J Clin 2018;68:7-30.

- 5 Llovet JM, Ricci S, Mazzaferro V, Hilgard P, Gane E, Blanc JF, de Oliveira AC, Santoro A, Raoul JL, Forner A, Schwartz M, Porta C, Zeuzem S, Bolondi L, Greten TF, Galle PR, Seitz JF, Borbath I, Haussinger D, Giannaris T, et al.: Sorafenib in advanced hepatocellular carcinoma. N Engl J Med 2008;359:378-390.

6 Trachootham D, Alexandre J, Huang P: Targeting cancer cells by ROS-mediated mechanisms: a radical therapeutic approach? Nat Rev Drug Discov 2009;8:579-591.

7 Panieri E, Santoro MM: ROS homeostasis and metabolism: a dangerous liason in cancer cells. Cell Death Dis 2016;7:e2253.

8 Llovet JM, Zucman-Rossi J, Pikarsky E, Sangro B, Schwartz M, Sherman M, Gores G: Hepatocellular carcinoma. Nat Rev Dis Primers 2016;2:16018.

9 Tell G, Vascotto C, Tiribelli C: Alterations in the redox state and liver damage: hints from the EASL Basic School of Hepatology. J Hepatol 2013;58:365-374. 


\section{Cellular Physiology Cell Physiol Biochem 2019:52:119-140 \\ \begin{tabular}{ll|l}
\cline { 2 - 3 } DOI: 10.33594/000000009 & (c) 2019 The Author(s). Published by
\end{tabular} \\ and Biochemistry Published online: 18 February 2019 Cell Physiol Biochem Press GmbH\&Co. KG \\ Smolková et al.: Molecular Mechanisms of Non-Thermal Plasma Action on Cancer Cells}

10 Bjelakovic G, Nikolova D, Gluud LL, Simonetti RG, Gluud C: Mortality in randomized trials of antioxidant supplements for primary and secondary prevention: systematic review and meta-analysis. JAMA 2007;297:842-857.

11 Harris IS, Brugge JS: CANCER The enemy of my enemy is my friend. Nature 2015;527:170-171.

- 12 Sun C, Wang ZH, Liu XX, Yang LN, Wang Y, Liu Y, Mao AH, Liu YY, Zhou X, Di CX, Gan L, Zhang H: Disturbance of redox status enhances radiosensitivity of hepatocellular carcinoma. Am J Cancer Res 2015;5:1368-1381.

- 13 Tien Kuo M, Savaraj N: Roles of reactive oxygen species in hepatocarcinogenesis and drug resistance gene expression in liver cancers. Mol Carcinog 2006;45:701-709.

- 14 Coriat R, Nicco C, Chereau C, Mir O, Alexandre J, Ropert S, Weill B, Chaussade S, Goldwasser F, Batteux F: Sorafenib-induced hepatocellular carcinoma cell death depends on reactive oxygen species production in vitro and in vivo. Mol Cancer Ther 2012;11:2284-2293.

15 Hou JK, Huang Y, He W, Yan ZW, Fan L, Liu MH, Xiao WL, Sun HD, Chen GQ: Adenanthin targets peroxiredoxin I/II to kill hepatocellular carcinoma cells. Cell Death Dis 2014;5:e1400.

16 Llovet JM, Hernandez-Gea V: Hepatocellular carcinoma: reasons for phase III failure and novel perspectives on trial design. Clin Cancer Res 2014;20:2072-2079.

17 Lee JM, Han KH: Positioning and indication of sorafenib in the treatment algorithm and real practice setting: Western and eastern approach--Asian perspective. Oncology 2010;78:167-171.

18 Babaeva NY, Naidis GV: Modeling of plasmas for biomedicine. Trends Biotechnol 2018;36:603-614.

- 19 Keidar M, Yan D, Beilis, II, Trink B, Sherman JH: Plasmas for treating cancer: opportunities for adaptive and self-adaptive approaches. Trends Biotechnol 2018;36:586-593.

20 Lu X, Naidis GV, Laroussi M, Reuter S, Graves DB, Ostrikov K: Reactive species in non-equilibrium atmospheric-pressure plasmas: Generation, transport, and biological effects. Phys Rep 2016;630:1-84.

- 21 Lunov O, Zablotskii V, Churpita O, Jager A, Polivka L, Sykova E, Dejneka A, Kubinova S: The interplay between biological and physical scenarios of bacterial death induced by non-thermal plasma. Biomaterials 2016;82:71-83.

22 Park JY, Park S, Choe W, Yong HI, Jo C, Kim K: Plasma-functionalized solution: a potent antimicrobial agent for biomedical applications from antibacterial therapeutics to biomaterial surface engineering. ACS Appl Mater Interfaces 2017;9:43470-43477.

23 Jang JY, Hong YJ, Lim J, Choi JS, Choi EH, Kang S, Rhim H: Cold atmospheric plasma (CAP), a novel physicochemical source, induces neural differentiation through cross-talk between the specific RONS cascade and Trk/Ras/ERK signaling pathway. Biomaterials 2018;156:258-273.

24 Isbary G, Heinlin J, Shimizu T, Zimmermann JL, Morfill G, Schmidt HU, Monetti R, Steffes B, Bunk W, Li Y, Klaempfl T, Karrer S, Landthaler M, Stolz W: Successful and safe use of 2 min cold atmospheric argon plasma in chronic wounds: results of a randomized controlled trial. Brit J Dermatol 2012;167:404-410.

- 25 Kubinova S, Zaviskova K, Uherkova L, Zablotskii V, Churpita O, Lunov O, Dejneka A: Non-thermal air plasma promotes the healing of acute skin wounds in rats. Sci Rep 2017;7:45183.

26 Yoon YJ, Suh MJ, Lee HY, Lee HJ, Choi EH, Moon IS, Song K: Anti-tumor effects of cold atmospheric pressure plasma on vestibular schwannoma demonstrate its feasibility as an intra-operative adjuvant treatment. Free Radic Biol Med 2018;115:43-56.

- 27 Hirst AM, Simms MS, Mann VM, Maitland NJ, O'Connell D, Frame FM: Low-temperature plasma treatment induces DNA damage leading to necrotic cell death in primary prostate epithelial cells. Br J Cancer 2015;112:1536-1545.

28 Shi L, Ito F, Wang Y, Okazaki Y, Tanaka H, Mizuno M, Hori M, Hirayama T, Nagasawa H, Richardson DR, Toyokuni S: Non-thermal plasma induces a stress response in mesothelioma cells resulting in increased endocytosis, lysosome biogenesis and autophagy. Free Radic Biol Med 2017;108:904-917.

29 Kang SU, Cho JH, Chang JW, Shin YS, Kim KI, Park JK, Yang SS, Lee JS, Moon E, Lee K, Kim CH: Nonthermal plasma induces head and neck cancer cell death: the potential involvement of mitogen-activated protein kinase-dependent mitochondrial reactive oxygen species. Cell Death Dis 2014;5:e1056.

30 Lunov O, Zablotskii V, Churpita O, Lunova M, Jirsa M, Dejneka A, Kubinova S: Chemically different nonthermal plasmas target distinct cell death pathways. Sci Rep 2017;7:600.

- 31 Bekeschus S, Kolata J, Winterbourn C, Kramer A, Turner R, Weltmann KD, Broker B, Masur K: Hydrogen peroxide: A central player in physical plasma-induced oxidative stress in human blood cells. Free Radic Res 2014;48:542-549. 


\section{Cellular Physiology Cell Physiol Biochem 2019:52:119-140 \begin{tabular}{ll|l}
\cline { 2 - 3 } DOI: 10.33594/000000009 & (c) 2019 The Author(s). Published by
\end{tabular} and Biochemistry Published online: 18 February 2019 Cell Physiol Biochem Press GmbH\&Co. KG

32 Lunov O, Zablotskii V, Churpita O, Jaeger A, Polivka L, Sykova E, Terebova N, Kulikov A, Kubinova S, Dejneka A: Towards the understanding of non-thermal air plasma action: effects on bacteria and fibroblasts. RSC Adv 2016;6:25286-25292.

- 33 Flynn PB, Busetti A, Wielogorska E, Chevallier OP, Elliott CT, Laverty G, Gorman SP, Graham WG, Gilmore BF: Non-thermal plasma exposure rapidly attenuates bacterial AHL-dependent quorum sensing and virulence. Sci Rep 2016;6:26320.

- 34 Laroussi M, Leipold F: Evaluation of the roles of reactive species, heat, and UV radiation in the inactivation of bacterial cells by air plasmas at atmospheric pressure. Int J Mass Spectrom 2004;233:81-86.

- 35 Kang MA, So EY, Simons AL, Spitz DR, Ouchi T: DNA damage induces reactive oxygen species generation through the H2AX-Nox1/Rac1 pathway. Cell Death Dis 2012;3:e249.

36 Zuliani T, Duval R, Jayat C, Schnebert S, Andre P, Dumas M, Ratinaud MH: Sensitive and reliable JC-1 and TOTO-3 double staining to assess mitochondrial transmembrane potential and plasma membrane integrity: interest for cell death investigations. Cytometry A 2003;54:100-108.

37 Lynnyk A, Lunova M, Jirsa M, Egorova D, Kulikov A, Kubinova S, Lunov O, Dejneka A: Manipulating the mitochondria activity in human hepatic cell line Huh7 by low-power laser irradiation. Biomed Opt Express 2018;9:1283-1300.

- 38 Lunova M, Prokhorov A, Jirsa M, Hof M, Olzynska A, Jurkiewicz P, Kubinova S, Lunov O, Dejneka A: Nanoparticle core stability and surface functionalization drive the mTOR signaling pathway in hepatocellular cell lines. Sci Rep 2017;7:16049.

- 39 Lunov O, Syrovets T, Rocker C, Tron K, Nienhaus GU, Rasche V, Mailander V, Landfester K, Simmet T: Lysosomal degradation of the carboxydextran shell of coated superparamagnetic iron oxide nanoparticles and the fate of professional phagocytes. Biomaterials 2010;31:9015-9022.

- 40 Franken NA, Rodermond HM, Stap J, Haveman J, van Bree C: Clonogenic assay of cells in vitro. Nat Protoc 2006;1:2315-2319.

- 41 Zimmermann H, Gerhard D, Dingermann T, Hothorn LA: Statistical aspects of design and validation of microtitre-plate-based linear and non-linear parallel in vitro bioassays. Biotechnol J 2010;5:62-74.

42 Hamilton N: Quantification and its applications in fluorescent microscopy imaging. Traffic 2009;10:951961.

- 43 Dell RB, Holleran S, Ramakrishnan R: Sample size determination. ILAR J 2002;43:207-213.

- 44 Weissgerber TL, Milic NM, Winham SJ, Garovic VD: Beyond bar and line graphs: time for a new data presentation paradigm. PLoS Biol 2015;13:e1002128.

- 45 Shi L, Wang Y, Ito F, Okazaki Y, Tanaka H, Mizuno M, Hori M, Richardson DR, Toyokuni S: Biphasic effects of l-ascorbate on the tumoricidal activity of non-thermal plasma against malignant mesothelioma cells. Arch Biochem Biophys 2016;605:109-116.

46 Ma Y, Ha CS, Hwang SW, Lee HJ, Kim GC, Lee KW, Song K: Non-thermal atmospheric pressure plasma preferentially induces apoptosis in p53-mutated cancer cells by activating ROS stress-response pathways. PLoS One 2014;9:e91947.

> 47 Tanaka H, Mizuno M, Ishikawa K, Takeda K, Hashizume H, Nakamura K, Utsumi F, Kajiyama H, Okazaki Y, Toyokuni S, Akiyama S, Maruyama S, Kikkawa F, Hori M: Glioblastoma cell lines display different sensitivities to plasma-activated medium. IEEE Trans Radiat Plasma Med Sci 2018;2:99-102.

- 48 Zhang XH, Li MJ, Zhou RL, Feng KC, Yang SZ: Ablation of liver cancer cells in vitro by a plasma needle. Appl Phys Lett 2008;93:021502.

49 Yan X, Xiong ZL, Zou F, Zhao SS, Lu XP, Yang GX, He GY, Ostrikov K: Plasma-Induced Death of HepG2 Cancer Cells: Intracellular Effects of Reactive Species. Plasma Process Polym 2012;9:59-66.

50 Zhao S, Xiong Z, Mao X, Meng D, Lei Q, Li Y, Deng P, Chen M, Tu M, Lu X, Yang G, He G: Atmospheric pressure room temperature plasma jets facilitate oxidative and nitrative stress and lead to endoplasmic reticulum stress dependent apoptosis in HepG2 cells. PLoS One 2013;8:e73665.

- 51 Poillet-Perez L, Despouy G, Delage-Mourroux R, Boyer-Guittaut M: Interplay between ROS and autophagy in cancer cells, from tumor initiation to cancer therapy. Redox Biol 2015;4:184-192.

- 52 Panieri E, Gogvadze V, Norberg E, Venkatesh R, Orrenius S, Zhivotovsky B: Reactive oxygen species generated in different compartments induce cell death, survival, or senescence. Free Radic Biol Med 2013;57:176-187.

- 53 Woo HA, Yim SH, Shin DH, Kang D, Yu DY, Rhee SG: Inactivation of peroxiredoxin I by phosphorylation allows localized H(2)O(2) accumulation for cell signaling. Cell 2010;140:517-528. 


\section{Cellular Physiology Cell Physiol Biochem 2019:52:119-140 \\ \begin{tabular}{l|l|l}
\cline { 2 - 3 } DOI: 10.33594/000000009 & (c) 2019 The Author(s). Published by
\end{tabular} \\ and Biochemistry Published online: 18 February 2019 Cell Physiol Biochem Press GmbH\&Co. KG \\ Smolková et al.: Molecular Mechanisms of Non-Thermal Plasma Action on Cancer Cells}

$>54$

55

$>56$

$>57$

$>58$

$>59$

140

60 Wong GS, Lee JS, Park YY, Klein-Szanto AJ, Waldron TJ, Cukierman E, Herlyn M, Gimotty P, Nakagawa H, Rustgi AK: Periostin cooperates with mutant p53 to mediate invasion through the induction of STAT1 signaling in the esophageal tumor microenvironment. Oncogenesis 2013;2:e59.

61 Li W, Yu KN, Ma J, Shen J, Cheng C, Zhou F, Cai Z, Han W: Non-thermal plasma induces mitochondriamediated apoptotic signaling pathway via ROS generation in HeLa cells. Arch Biochem Biophys 2017;633:68-77.

Bieging KT, Mello SS, Attardi LD: Unravelling mechanisms of p53-mediated tumour suppression. Nat Rev Cancer 2014;14:359-370.

Blandino G, Di Agostino S: New therapeutic strategies to treat human cancers expressing mutant p53 proteins. J Exp Clin Cancer Res 2018;37:30.

Cagatay T, Ozturk M: P53 mutation as a source of aberrant beta-catenin accumulation in cancer cells. Oncogene 2002;21:7971-7980.

Vaseva AV, Moll UM: The mitochondrial p53 pathway. Biochim Biophys Acta 2009;1787:414-420.

Ni Z, Wang B, Dai X, Ding W, Yang T, Li X, Lewin S, Xu L, Lian J, He F: HCC cells with high levels of Bcl-2 are resistant to ABT-737 via activation of the ROS-JNK-autophagy pathway. Free Radic Biol Med 2014;70:194203.

Towers CG, Thorburn A: Targeting the Lysosome for Cancer Therapy. Cancer Discov 2017;7:1218-1220. Erdal H, Berndtsson M, Castro J, Brunk U, Shoshan MC, Linder S: Induction of lysosomal membrane permeabilization by compounds that activate p53-independent apoptosis. Proc Natl Acad Sci U S A 2005;102:192-197.

- 69 Meissl K, Macho-Maschler S, Muller M, Strobl B: The good and the bad faces of STAT1 in solid tumours. Cytokine 2017;89:12-20.

$>70$ Yoshida T, Ogata H, Kamio M, Joo A, Shiraishi H, Tokunaga Y, Sata M, Nagai H, Yoshimura A: SOCS1 is a suppressor of liver fibrosis and hepatitis-induced carcinogenesis. J Exp Med 2004;199:1701-1707.

- 71 Calvisi DF, Ladu S, Gorden A, Farina M, Conner EA, Lee JS, Factor VM, Thorgeirsson SS: Ubiquitous activation of Ras and Jak/Stat pathways in human HCC. Gastroenterology 2006;130:1117-1128.

- 72 Tuhvatulin AI, Sysolyatina EV, Scheblyakov DV, Logunov DY, Vasiliev MM, Yurova MA, Danilova MA, Petrov OF, Naroditsky BS, Morfill GE, Grigoriev AI, Fortov VE, Gintsburg AL, Ermolaeva SA: Non-thermal Plasma Causes p53-Dependent Apoptosis in Human Colon Carcinoma Cells. Acta Naturae 2012;4:82-87.

73 Lee S, Lee H, Jeong D, Ham J, Park S, Choi EH, Kim SJ: Cold atmospheric plasma restores tamoxifen sensitivity in resistant MCF-7 breast cancer cell. Free Radic Biol Med 2017;110:280-290.

74 Kaushik N, Uddin N, Sim GB, Hong YJ, Baik KY, Kim CH, Lee SJ, Kaushik NK, Choi EH: Responses of solid tumor cells in DMEM to reactive oxygen species generated by non-thermal plasma and chemically induced ROS systems. Sci Rep 2015;5:8587. 